\title{
ARTICLE
}

\section{Effect of nitrate and irradiance on fatty acid production in microalgae cultivated for feeding larvae and broodstock conditioning in batch culture}

Efectos de nitrato e irradiación en la producción de ácidos grasos en microalgas destinadas a la alimentación de larvas y reproductores, en cultivo experimental cerrado

\section{Fidelina González ${ }^{1 *}$, Katia Sáez², María Eliana Vega ${ }^{3}$, Berenice Bizama ${ }^{4}$, José Becerra $^{5}$, Irene Lépez ${ }^{6}$, Víctor Hernández ${ }^{5}$ and Mario Silva ${ }^{5}$}

\author{
'Departamento de Biología Celular, Facultad de Ciencias Biológicas, Universidad de Concepción, casilla 160-C, código postal 4089100, \\ Concepción, Chile \\ ${ }^{2}$ Departamento de Estadística. Facultad de Ciencias Físicas y Matemáticas, Universidad de Concepción, casilla 160-C, Concepción, Chile \\ ${ }^{3}$ Consultoría Ambiental en Empresa Independiente, Chile \\ ${ }^{4}$ Subsecretaría de Pesca y Acuicultura, SUBPESCA, Dirección Zonal de Pesca y Acuicultura de la Región del Biobío y Nuble, Tucapel \\ 279, Concepción, Chile \\ ${ }^{5}$ Laboratorio de Química de Productos Naturales, Departamento de Botánica, Facultad de Ciencias Naturales y Oceanográficas, Universidad \\ de Concepción, casilla 160-C, Concepción, Chile \\ ${ }^{6}$ Retired (Jubilada), Chile \\ *Autor corresponsal: fgonzale@udec.cl
}

Resumen.- El objetivo de este estudio fue comparar las condiciones para producir altos niveles de AGPI, EPA y DHA en microalgas cultivadas para alimentar las etapas larvarias de los bivalvos. Se evaluó por cromatografía de gas la concentración de ácidos grasos poliinsaturados en tres especies de microalgas, Isochrysis galbana Parke (T-ISO), Chaetoceros gracilis Pantocsek y C. constrictus Gran, con el fin de ser usadas como fuente de alimento de larvas y adultos de bivalvos en cultivo. Isochrysis galbana produce mayor concentración de ácido linolénico y ácido docosahexaenoico que ácido eicosapentaenoico en condiciones limitantes de nitrato, sin embargo estos ácidos grasos se incrementan notablemente con el exceso de $\mathrm{N}$-nitrato, por encima del contenido del medio $\mathrm{F} / 2$. Por otra parte, la baja intensidad lumínica y la concentración normal de nitratos en los cultivos de la especie Chaetoceros gracilis producen mayor contenido de ácido eicosapentaenoico (EPA). En el caso de Chaetoceros constrictus, la microalga sintetiza mayor concentración de ácidos grasos en condiciones de alta intensidad lumínica y bajas concentraciones de nitrato.

Palabras clave: Microalgas, ácidos grasos, ácido eicosapentaenoico

\begin{abstract}
The aim of this study was to compare conditions for the production of high levels of PUFA, EPA and DHA in cultured microalgae for larval bivalve feeding stages. It assessed fatty acid composition by gas chromatography for Isochrysis galbana Parke (T-ISO) and 2 species of Chaetoceros, C. gracilis Pantocsek and C. constrictus Gran. Species were studied in batch cultures, at the beginning of stationary growth phase with different irradiance and 2 levels of nitrogen content for Chaetoceros sp., and constant irradiance with 5 concentrations of sodium nitrate for I. galbana in an F/2 medium. Isochrysis galbana produced higher levels of linolenic acid and docosahexaenoic acid than eicosapentaenoic acid (EPA) at low N-nitrate concentrations; however, fatty acids increased notably with surplus N-nitrate, above F/2 medium content. Low irradiance and normal concentration of nitrates in the batches of Chaetoceros gracilis species produced a greater EPA content. C. constrictus, a diatom isolated from phytoplankton samples, presented higher levels of EPA and DHA at low levels of nitrogen and low irradiance.
\end{abstract}

Key words: Microalgae, fatty acids, eicosapentaenoic acid

\section{INTRODUCTION}

Microalgae play an important role in aquaculture as feed for larvae and adult conditioning for marine invertebrate species; nutritional value is related to biochemical composition, and broodstock adult conditioning is especially important for the following developmental stages. When dietary nutritional value is high in polyunsaturated fatty acids (PUFAs), successful oyster spatfalls are produced (Fakhrina \& Christianus 2018). Oyster larvae accumulate lipid reserves, and larvae with higher reserves are more competent at settling than those with lower reserves (Liang et al. 2006). Marine microalgae are an important feed source in aquaculture, being used in hatcheries to feed bivalves such as Argopecten purpuratus (Cerpa et al. 2003) as well as fish (Hamre et al. 2013). Long-chain polyunsaturated fatty acids (LC-PUFAs), namely eicosapentaenoic acid (20:5 n-3, EPA), docosahexaenoic acid (22:6 n-3, DHA) and arachidonic acid (20:4 n-6, ARA), are considered essential fatty acids (EFAs) in teleosts for both natural environments (Castro et al. 2010) and hatchery conditions, 
as a source of metabolic energy and cell membrane structure (Bonacic et al. 2016). As metabolism regulators, long chain polyunsaturated fatty acid derivatives, such as leukotriene, act in extracellular or intracellular ligands as transcription factors that control gene expression (Tocher 2015, Bonacic et al. 2016).

Lipid composition varies according to irradiance, culture medium nutrient composition for microalgae and species, and it is usually necessary to mix different species to offer balanced nutrition for larvae (Cerpa et al. 2003, Hemaiswarya et al. 2011, Guevara et al. 2016). The most important aspect of lipids in animal nutrition is the content and proportion of certain fatty acids. In particular, some polyunsaturated fatty acids (PUFAs) synthesized by algae are essential for the growth and development of marine fish, shrimp and mollusk larvae (Adarme-Vega et al. 2012). The presence of long unsaturated fatty acids is important when selecting microalgae for aquaculture processes, and different species of microalgae have different metabolic ability for optimal synthesis. Unsaturated long chain fatty acids are synthesized by elongases and desaturases from palmitic, stearic or oleic acid in plastids and rough endoplasmic reticulum (Mühlroth et al. 2013). Meanwhile, in plastids, membrane structural lipid synthesis occurs in the rough endoplasmic reticulum, along with those that store energy, such as triacylglicerols (TAG) (Bellou et al 2014).

Nitrogen availability affects the synthesis and accumulation of metabolites such as lipids, pigments and cell components (Lourenço et al. 2002). It is possible to change the lipid composition of microalgae, varying culture conditions near to metabolic stress (Gordillo et al. 1998, Yu et al. 2011, Benavente-Valdés et al. 2016, Minhas et al. 2016). Among different culture medium components, the source and concentration of nitrogen can induce significant changes in growth and biochemical composition, particularly with respect to the lipid composition (Madkour et al. 2012, Zhang et al. 2013, Kim et al. 2016). Therefore, it was tested different culture conditions that could increase unsaturated fatty acids in 2 species, Isochrysis galbana, Chaetoceros gracilis, as well as a wild microalga, Chaetoceros constrictus, under batch conditions. The aim of this study was to compare conditions for producing high levels of PUFA, EPA and DHA to improve growth efficiency for larval bivalve feeding stages in hatchery only changing culture conditions in microalgae production (temperature and irradiance) according to nutrient necessity of larval stage.

\section{Materials AND MethodS}

The experimental design was performed on 3 species, 2 of which are traditionally used for feeding in bivalve hatcheries, e.g., Argopecten purpuratus (Cerpa et al. 2003): Isochrysis galbana (T-ISO) and tropical Chaetoceros gracilis. Chaetoceros constrictus was isolated from wild phytoplankton samples.

Isochrysis galbana (T-ISO) (Haptophyta) was isolated from $50 \mathrm{~L}$ pure mass culture containers for massive bivalves feeding in hatchery cultures. An experimental culture was made in 3 bags of $0.3 \mathrm{~mm}$ thick polyethylene, in a volume of $20 \mathrm{~L}$ of sea water filtered and sterilized with UV light and 5 ppm sodium hypochlorite for $30 \mathrm{~min}$, to standardize fatty acid and protein extraction. We added $\mathrm{F} / 2$ culture medium containing $75 \mathrm{mg} \mathrm{L}^{-1}$ of sodium nitrate. It was inoculated with $2 \mathrm{~L}$ of microalga, under constant aeration conditions, with a photoperiod of $12: 12$, at a temperature of $20 \pm 1{ }^{\circ} \mathrm{C}$ and photonic flow of 60 to $70 \mu \mathrm{E} \mathrm{m}^{-2} \mathrm{~s}^{-1}$. The microalgae were harvested at the end of the exponential phase (6-7 days)/ beginning of the stationary phase (Roopnarain et al. 2015).

\section{EXPERIMENTAL DESIGN}

One hundred $\mathrm{mL}$ of culture at exponential growth phase, with an initial concentration of 75,000 cells $\mathrm{mL}^{-1}$ was transferred to $5 \mathrm{~L}$ bottles, with modified $\mathrm{F} / 2$ or $\mathrm{F} / 2$ culture medium. Samples of T-ISO were grown under 5 different concentrations of sodium nitrate $(20,40,75,160,320 \mathrm{mg}$ $\mathrm{L}^{-1}$ in duplicate). The culture conditions were photoperiods of 16:8, with constant aeration and photonic flow from 60 to $70 \mu \mathrm{Em}^{-2} \mathrm{~s}^{-1}$, with vertical fluorescent tubes, at $20-23{ }^{\circ} \mathrm{C}$.

Cell growth was quantified with a Neubauer counting chambers with samples stained with lugol according to Ramírez (1982).

Conditions for growing $C$. gracilis Pantocsek (Bacillariophyta), a microalga strain commonly used for feeding bivalves at Universidad de Concepción hatchery (Cerpa et al. 2003). From a culture bag, it was obtained 50 $\mathrm{mL}$ of $C$. gracilis culture, during the stationary growth phase at $200 \mu \mathrm{Em}^{-2} \mathrm{~s}^{-1}, 20{ }^{\circ} \mathrm{C}$, and put in a $5 \mathrm{~L}$ flask at $40 \mu \mathrm{Em}^{-2}$ $\mathrm{s}^{-1}$, with $16: 8$, at $15^{\circ} \mathrm{C}$ for acclimatization, for 4 days. Then, we added it to 12 flasks of $350 \mathrm{~mL}$, provided with $200 \mathrm{~mL}$ of $\mathrm{F} / 2$ by an air pump.

Wild Chaetoceros constrictus was isolated from phytoplankton samples obtained at Coliumo Bay (Dichato, $36^{\circ} 32^{\prime} \mathrm{S}, 72^{\circ} 57^{\prime} \mathrm{W}$ ), with a phytoplankton net of $32 \mu \mathrm{m}$ mesh, identified and kept under constant photonic flux of $60 \mu \mathrm{Em}^{-2} \mathrm{~s}^{-1}$, at $18{ }^{\circ} \mathrm{C}$. Acclimatization of the cultures was performed at $30 \mu \mathrm{Em}^{-2} \mathrm{~s}^{-1}$, with a photoperiod of $16: 8$, at $15^{\circ} \mathrm{C}$. Constant air pumping was maintained for a further 2 weeks. Massive cultures were settled 2 weeks later, in 5 L glass bottles. 
Twelve $250 \mathrm{~mL}$ flasks were distributed in groupings of two. Groups of 4 flasks were cultured at the same light intensity: 30,60 or $100 \mu \mathrm{Em}^{-2} \mathrm{~s}^{-1}$, provided with fluorescence tubes. In each group, 2 of 4 flasks were used for culture at high sodium nitrate $\left(\mathrm{NaNO}_{3}\right)$ concentration $\left(75 \mathrm{mg} \mathrm{L}^{-1}\right)$, which is the normal concentration of $\mathrm{F} / 2$ medium culture, or low concentration $\left(37.5 \mathrm{mg} \mathrm{L}^{-1}\right)$, at $15-16{ }^{\circ} \mathrm{C}$. In total, there were 6 different growing conditions for the 2 species of Chaetoceros sp. (Table 1).

\section{Mass Culture}

For both Chaetoceros species, bulk cultures were prepared in $5 \mathrm{~L}$ sterilized bottles with $\mathrm{F} / 2$ culture medium. A 200 $\mathrm{mL}$ culture sample in its exponential phase was inoculated. The harvest was performed at the beginning of the algae's stationary phase (15 days in C. gracilis, 13 days in $C$. constrictus). Cultures of $C$. gracilis were centrifuged at $3500 \mathrm{rpm}$ for $10 \mathrm{~min}$. Cultures of $C$. constrictus were settled for $4 \mathrm{~h}$, and the culture medium sucked out. The pellets were centrifuged at $4500 \mathrm{rpm}$ for $15 \mathrm{~min}$. The pellets obtained were frozen at $-4{ }^{\circ} \mathrm{C}$ and lyophilized for $24 \mathrm{~h}$ in LABCONCO Lyphlock 4.5 lyophilizer at $-50{ }^{\circ} \mathrm{C}$ and 0.05 $\mathrm{mBar}$ pressures to a constant weight.

Microalgae growth was calculated based on daily sampling in triplicates.

\section{Microalgae fatty ACID Production}

Total lipids were extracted according to Folch et al. (1957), and determined gravimetrically after solvent evaporation. 100 to $250 \mathrm{mg}$ of lyophilized sample was extracted with 30 $\mathrm{mL}$ chlorophorm: methanol at 2:1 for $30 \mathrm{~min}$, sonicated, as recommended by Ryckebosch et al. (2013, 2014a,b). Aliquots of the final lipid extracts were deposited in chloroform, and used to prepare the fatty acid methyl esters (FAME) with $12 \% \mathrm{BF}_{3}$ (Metcalfe et al. 1966). GC-F1-547 was used for gas chromatography analysis with a flame ionization detector at $5 \mathrm{~m} \mathrm{x} 0.25 \mathrm{~mm}$ ID capillary column (20 $\mathrm{m}$ in length). The temperature for this programmed operation was initially $50{ }^{\circ} \mathrm{C}$, increasing to $150{ }^{\circ} \mathrm{C}$ at 8 ${ }^{\circ} \mathrm{C} \mathrm{min}-1$, then to $250{ }^{\circ} \mathrm{C}$ at $10{ }^{\circ} \mathrm{C} \mathrm{min}^{-1}$, and maintained at constant temperature for an additional $10 \mathrm{~min}$. Injector temperature was $250^{\circ} \mathrm{C}$, and detector temperature was 300 ${ }^{\circ} \mathrm{C}$ (El Menyawi et al. 2000, Cerpa et al. 2003). Nitrogen gas flow was $1 \mathrm{~mL} \mathrm{~min}{ }^{-1}$. Standard mixtures of fatty acid methyl esters (Supelco) were used to obtain relative retention times and identify fatty acids in the samples by comparison. Relative fatty acid levels were calculated as ng of fatty acid per $\mathrm{g}$ of dry sample, according to peak area compared to the standard for capric acid C10 (Santos et al. 2012). To determine saturated fatty acids, a standard was used with a mixture of fatty acids from C14 to C20; C 20:5 (n-3) eicosapentaenoic acid was determined with a standard at a concentration of $5 \mathrm{mg}$.

Table 1. Experimental design for Chaetoceros sp. irradiance ( 3 levels, as indicated in the second column) and sodium nitrate concentration ( 2 levels, as indicated in the fourth column) / Diseño experimental para intensidad lumínica en Chaetoceros sp. ( 3 niveles, como se indica en la segunda columna) y concentración de nitrato de sodio ( 2 niveles, como se indica en la cuarta columna)

\begin{tabular}{|c|c|c|c|c|c|}
\hline & \multirow{2}{*}{$\begin{array}{c}\text { Treatment } \\
\text { Control }\end{array}$} & \multirow{2}{*}{\multicolumn{2}{|c|}{$\begin{array}{ll} & \begin{array}{l}\text { Irradiance } \\
\mu \mathrm{Em}^{-2} \mathrm{~s}^{-1}\end{array} \\
60 & \text { Normal }(\mathrm{M})^{*}\end{array}$}} & \multicolumn{2}{|c|}{$\begin{array}{l}\text { Concentration of }\left[\mathrm{Na} \mathrm{NO}_{3}\right] \\
\text { in the culture media } \mathrm{mg} \mathrm{L}^{-1}\end{array}$} \\
\hline 1 & & & & 75 & $\operatorname{Normal}(\mathrm{A})^{* *}$ \\
\hline 2 & Experimental & 60 & $\operatorname{Normal}(\mathrm{M})^{* * *}$ & 37.5 & Stress (B) \\
\hline 3 & Experimental & 100 & $\operatorname{High}(\mathrm{A})$ & 75 & Normal (A) \\
\hline 4 & Experimental & 100 & High (A) & 37.5 & Stress (B) \\
\hline 5 & Experimental & 30 & Low (B) & 75 & Normal (A) \\
\hline 6 & Experimental & 30 & Low (B) & 37.5 & Stress (B) \\
\hline
\end{tabular}

$\left(^{*}\right)$ Letters between parentheses indicate a symbol for graphics

(**) Normal means sodium nitrate concentration in $\mathrm{F} / 2$ culture media

$(* * *)$ Normal irradiance is the habitual light intensity used in the hatchery cultivation Chaetoceros $\mathrm{sp}$. 


\section{Microalgae PROTEIN PRODUCTION}

Total proteins were determined using the method in Lowry et al. (1951), using $300 \mu \mathrm{g} \mathrm{mL}-1$ albumin solution as standard.

\section{STATISTICAL ANALYSIS}

Principal component analysis (PCA) was performed with the InfoStat program (Di Rienzo et al. 2015) for comparison of fatty acids profile in both species of Chaetoceros. The Pearson coefficient was also calculated to understand the possible relationship in metabolic pathways.

\section{RESULTS}

\section{ISOCHRYSIS GALBANA GROWTH}

Growth curves for different culture conditions of microalgae Isochrysis galbana (T-ISO) were obtained. In normal conditions, at a concentration of $75 \mathrm{mg} \mathrm{L}^{-1}$ sodium nitrate, an exponential cell growth was observed up to day 7 of culture, increasing to a maximum value of $12.81 * 10^{6}$ cells $\mathrm{mL}^{-1}$ At deficient concentrations of sodium nitrate, $(20$ and $40 \mathrm{mg}$ $\mathrm{L}^{-1}$ ), cell growth reached a maximum of 8.5 to $8.88 * 10^{6}$ cells $\mathrm{mL}^{-1}$, on day 7 of culture. Under higher sodium nitrate conditions, cell number responses at $160 \mathrm{mg} \mathrm{L}^{-1}$, reaching $14.26^{*} 10^{6}$ cells $\mathrm{mL}^{-1}$ from day 7 to day 14 . At $320 \mathrm{mg} \mathrm{L}^{-1}$ concentration, the number of cells increased from $11.45^{*} 10^{6}$ cells $\mathrm{mL}^{-1}$ per day to $13.36^{*} 10^{6}$ cells $\mathrm{mL}^{-1}$ per day by day 14. Figure 1 shows biomass (wet and dry weight) and cell density in the culture. Growth rate at harvesting time (day 7) was between 0.026 and $0.028 \mathrm{~h}^{-1}$.

\section{LIPID AND FATTY ACID CONTENTS OF ISOCHRYSIS}

Figure 2 shows the fatty acid profiles obtained with different concentrations of sodium nitrate contained in the $\mathrm{F} / 2$ culture medium. Fatty acids content increased at low concentrations of sodium nitrate and even more at high concentrations, especially at $160 \mathrm{mg} \mathrm{L}^{-1}$ sodium nitrate, reaching values of $63 \mathrm{mg} \mathrm{g}^{-1}$ lyophilized PUFA C18>2.

Lipid content increased in relation to dry weight both at low and high nitrate concentrations with respect to the normal medium (75 $\mathrm{mg} \mathrm{L}^{-1}$ sodium nitrate), as shown in Figure 2. Saturated (42\%) and monounsaturated fatty acid (40\%) contents were higher at low concentrations $\left(20 \mathrm{mg} \mathrm{L}^{-1}\right.$ of sodium nitrate). With high concentrations of sodium nitrate, monounsaturated fatty acids (MUFA) were not detected; saturated fatty acids were $29 \%$ and PUFAs were $71 \%$, of which the most important fatty acids were 18:> 2 and 22: $6 \omega 3$. The ratio of saturated fatty acids to total lipids was greatest for the lowest nitrate concentration $\left(20 \mathrm{mg} \mathrm{L}^{-1}\right)$, reaching $42 \%$, which decreased to $39 \%$ (at $40 \mathrm{mg} \mathrm{L}^{-1}$ ), 35\% (at $75 \mathrm{mg} \mathrm{L}^{-1}$ ), and $29 \%$ (at 160 and $320 \mathrm{mg} \mathrm{L}^{-1}$ ).

Protein concentration gradually increased as nitrate availability increased in the culture medium (Fig. 2). Protein content increased from $23 \%$ (at $20 \mathrm{mg} \mathrm{L}^{-1}$ ) to $56 \%$ lyophilized weight (at $320 \mathrm{mg} \mathrm{L}^{-1}$ ) in relation to nitrate concentration in the culture medium.

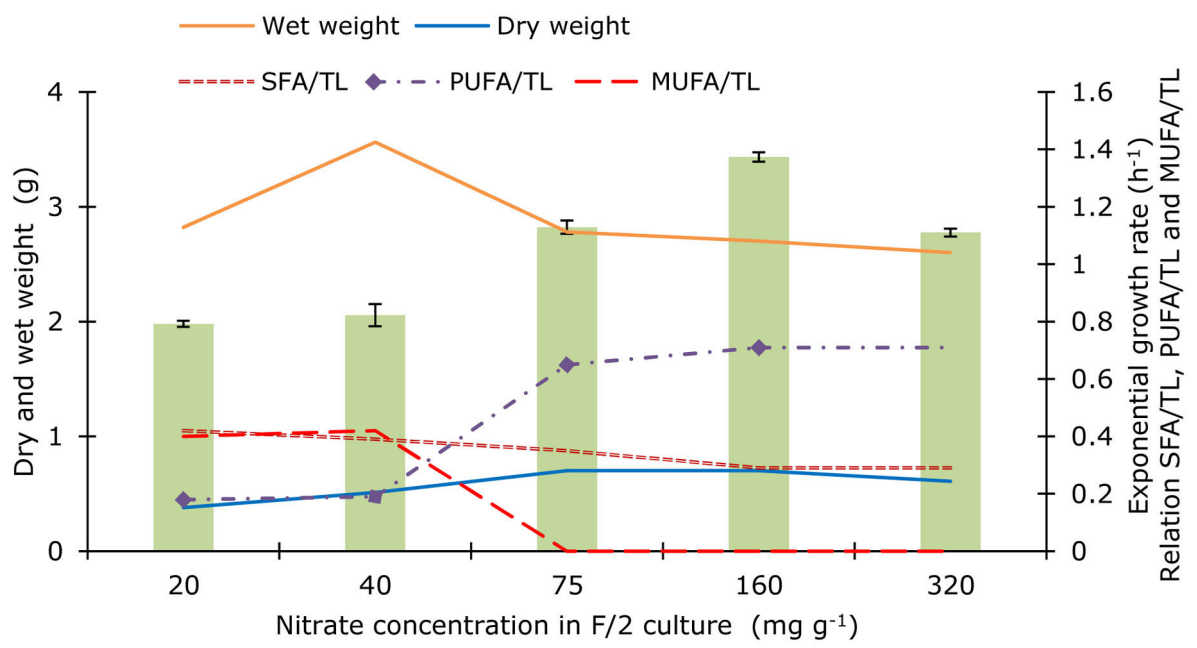

Figure 1. Biomass, number cells $\mathrm{mL}^{-1}$, and relation SFA/TL, PUFA/TL and MUFA/TL at the finishing of exponential growth rate in Isochrysis galbana (T-ISO) $\left(7^{\text {th }}\right.$ day of cultivation) / Biomasa, número de células $\mathrm{mL}^{-1}$ y relación SFA/TL, PUFA/TL y MUFA/TL al finalizar la tasa de crecimiento exponencial en Isochrysis galbana (T-ISO) (70 día de cultivo) 


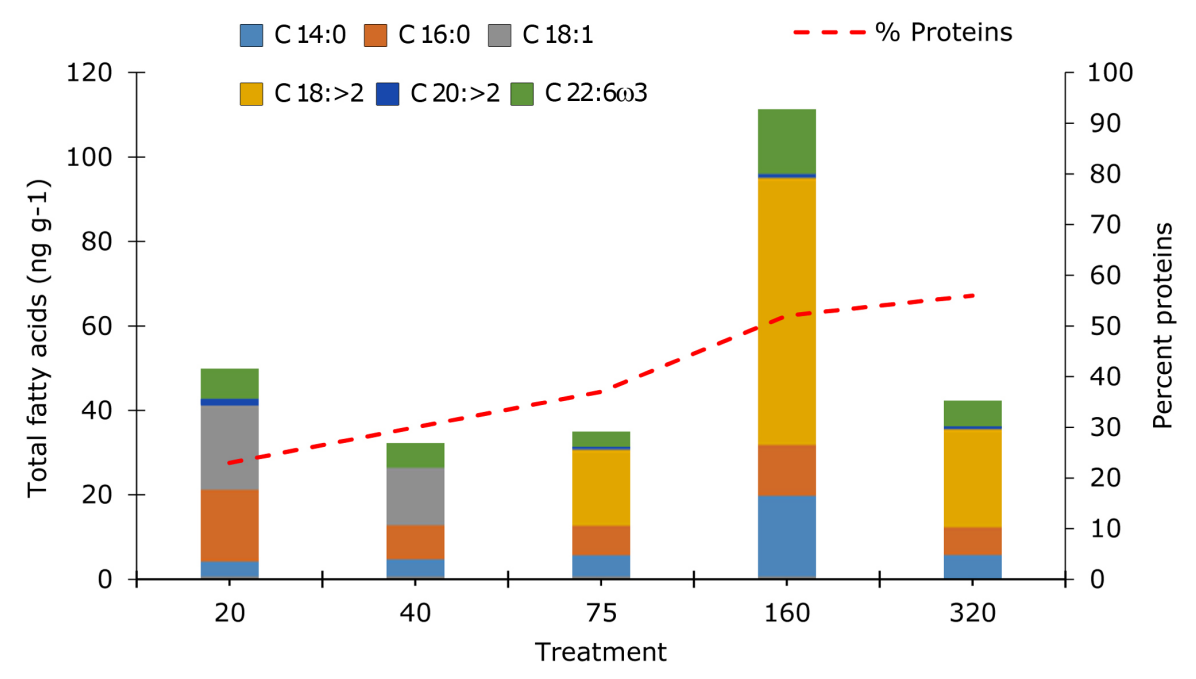

Figure 2. Distribution of total fatty acids and percent of total protein content for each nitrate concentration in Isochrysis galbana (T-ISO) in the culture medium: It is indicated in each bar, the fatty acid composition for each treatment / Distribución de ácidos grasos totales y porcentaje del contenido de proteína total para cada concentración de nitrato en Isochrysis galbana (T-ISO) en el medio de cultivo: En cada barra se indica la composición de ácidos grasos para cada tratamiento

a)

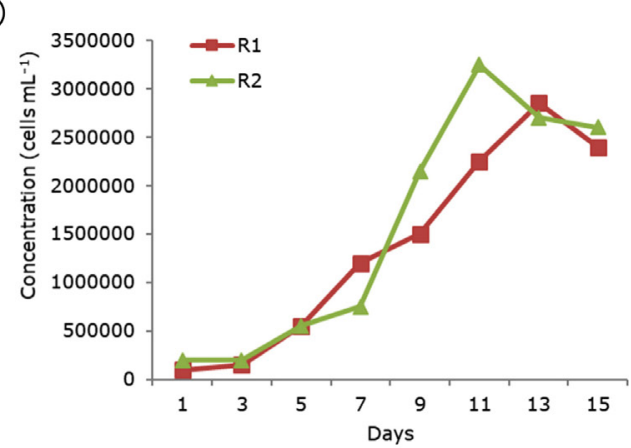

c)

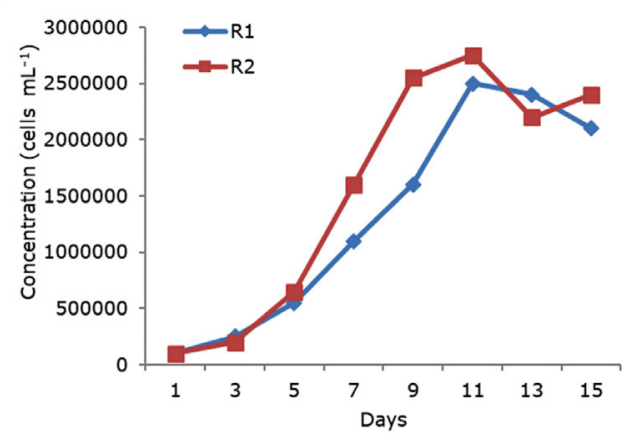

e)

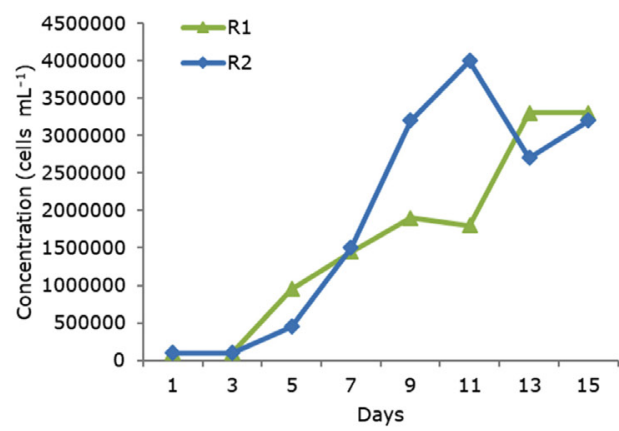

b)

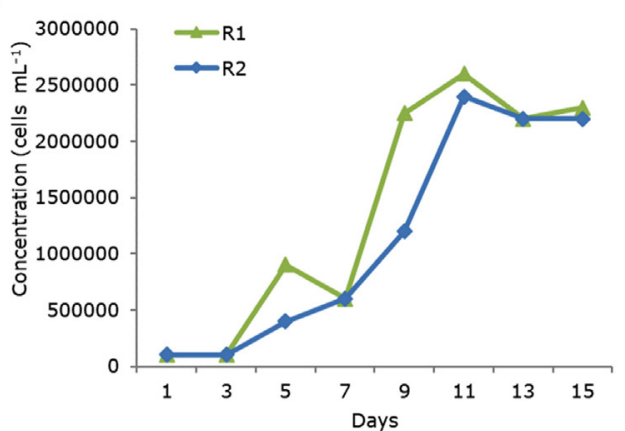

d)

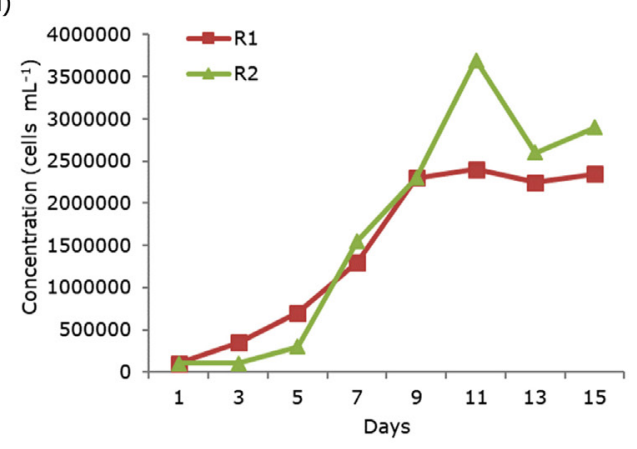

f)

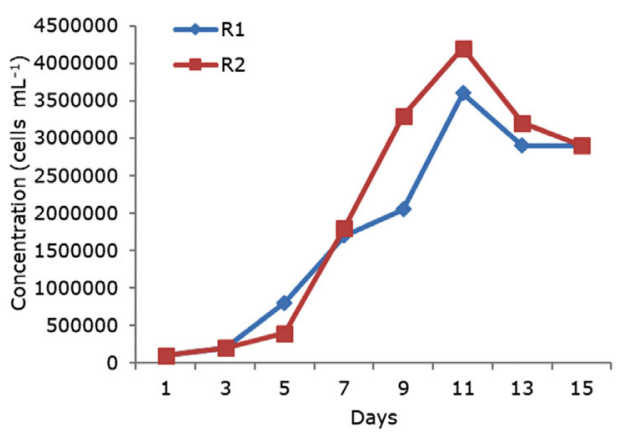

Figure 3. Growth curves of Chaetoceros gracilis cultures obtained from two replicates (R1, R2) at different experimental conditions of irradiance and sodium nitrate concentrations. Irradiance $30 \mu \mathrm{E} \mathrm{m}^{-2} \mathrm{~s}^{-1}(\mathrm{a}, \mathrm{b}) ; 60 \mu \mathrm{E} \mathrm{m}^{-2} \mathrm{~s}^{-1}(\mathrm{c}, \mathrm{d}) ; 100 \mu \mathrm{E} \mathrm{m}^{-2} \mathrm{~s}^{-1}$ (e, f). Sodium nitrate concentration $75 \mathrm{mg} \mathrm{mL}^{-1}$

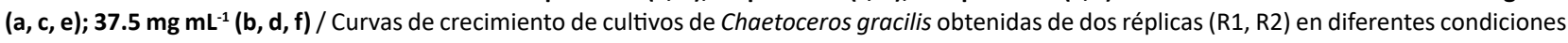
experimentales de intensidad lumínica $30 \mu \mathrm{E} \mathrm{m}^{-2} \mathrm{~s}^{-1}(\mathrm{a}, \mathrm{b}) ; 60 \mu \mathrm{E} \mathrm{m} \mathrm{s}^{-1}$ (c, d); $100 \mu \mathrm{E} \mathrm{m} \mathrm{m}^{-2} \mathrm{~s}^{-1}$ (e, f). Concentración de nitrato de sodio de $75 \mathrm{mg} \mathrm{mL}^{-1}$ $(a, c, e) ; 37,5 \mathrm{mg} \mathrm{mL}^{-1}(b, d, f)$ 


\section{CHAETOCEROS GRACILIS GROWTH}

During the exponential growth phase, we observed that cultures at low light intensity grew slower than those subjected to high intensity, regardless of nitrate concentration in the culture medium (Fig. 3a, c, e). During the final part of the exponential phase, culture growth rate tended to stabilize. On the eleventh day of culture, the stationary phase of growth started, with concentrations ranging from $2.5-4 \cdot 10^{6}$ cells $\mathrm{mL}^{-1}$. Cultures maintained at $100 \mu \mathrm{E} \mathrm{m}^{-2} \mathrm{~s}^{-1}$ reached greater cell density (Fig. 3e, f). There were no statistically significant differences $(P<0.05)$ in culture growth rates for the two nitrate concentration levels (Fig. 3 a-f).

\section{CHAETOCEROS CONSTRICTUS GROWTH}

During the exponential phase, cultures maintained at 30

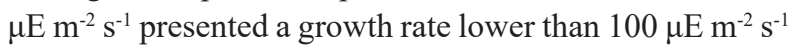
(Fig. 4a-d). There were no significant differences between nitrate concentration levels for the same light intensity. The highest density reached was $62 * 10^{4}$ cells $\mathrm{mL}^{-1}$ under high irradiance and normal nitrate levels (Fig. 4c).

a)

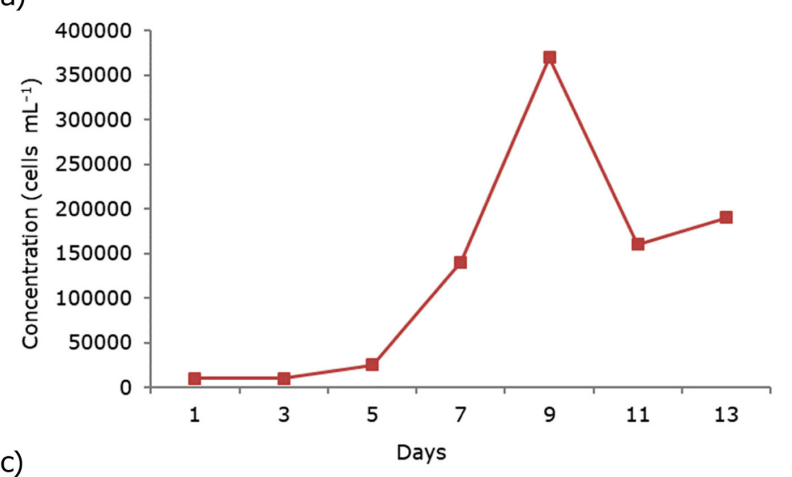

c)

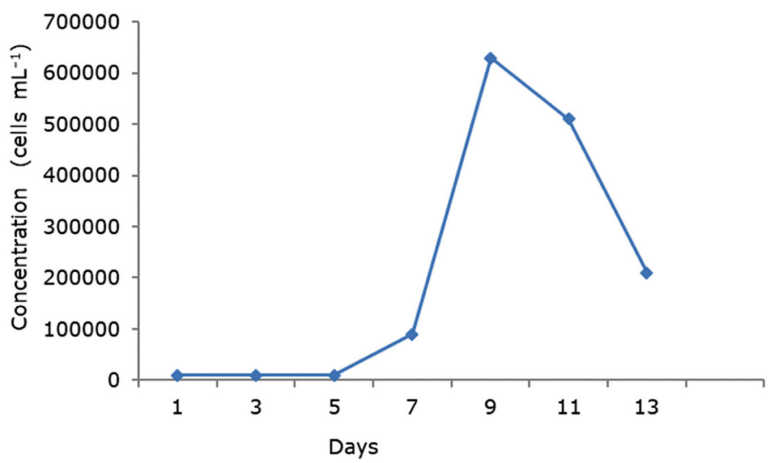

EFFECT OF SPECIES ON LIPID PRODUCTION IN CHAETOCEROS SPP.

Both species of Chaetoceros, in all conditions tested, produced on average, high proportions of the monounsaturated fatty acids C 16:1, followed by C 14:00, and then C 20:6.

C. gracilis produced more unsaturated fatty acids than C. constrictus, as the ratio of unsaturated/saturated fatty acids showed in Figure 5.

Total content of the main fatty acid groups for C. gracilis are shown in Figure 6 and C. constrictus in Figure 7. ANOVA of unsaturated C 18 (MUFA+PUFA) indicated that factor irradiance was statistically significant $(P=0.0055)$, as well as irradiance*nitrate $(P=0.0189)$, irradiance*sp $(P=$ $0.0005)$, nitrate* $\operatorname{sp}(P=0.0405)$. ANOVA of unsaturated $C$ 22 (PUFA) only presented statistically significant difference $(P=0.0516)$ when compared to irradiance*nitrate. In C. gracilis, the predominance of SFA is observed only when culture conditions were at normal irradiance. High irradiance allowed the accumulation of both unsaturated C 20 and C 22, with culture at normal nitrate F/2 (Fig. 6).

b)

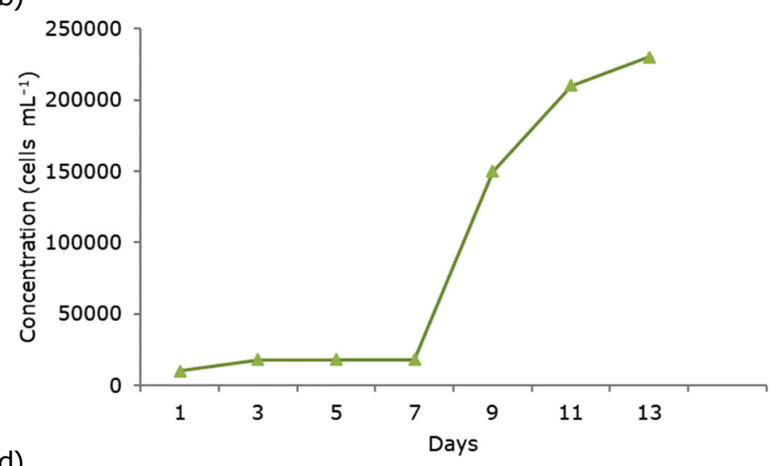

d)

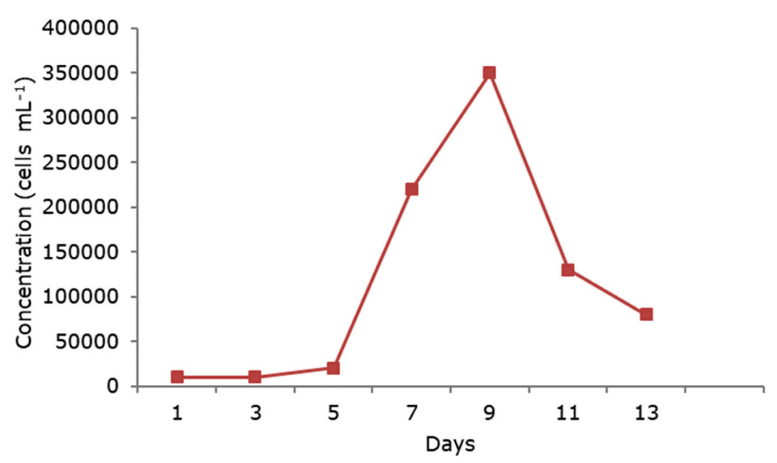

Figure 4. Growth curves of Chaetoceros constrictus cultures obtained at different experimental conditions of irradiance and sodium nitrate concentrations. a) Irradiance $30 \mu \mathrm{E} \mathrm{m}^{-2} \mathrm{~s}^{-1}(\mathrm{a}, \mathrm{b}) ; 100 \mu \mathrm{E} \mathrm{m}^{-2} \mathrm{~s}^{-1}\left(\mathrm{c}\right.$, d). Sodium nitrate concentration $75 \mathrm{mg} \mathrm{mL}^{-1}(\mathrm{a}, \mathrm{c}) ; 37.5 \mathrm{mg} \mathrm{mL}^{-1}$ (b, d) / Curvas de crecimiento de cultivos de Chaetoceros constrictus obtenidas en diferentes condiciones experimentales de intensidad lumínica y concentración de nitrato de sodio. Intensidad lumínica $30 \mu \mathrm{E} \mathrm{m}^{-2} \mathrm{~s}^{-1}(\mathrm{a}, \mathrm{b}) ; 100 \mu \mathrm{E} \mathrm{m}^{-2} \mathrm{~s}^{-1}(\mathrm{c}, \mathrm{d})$. Concentración de nitrato de sodio de $75 \mathrm{mg} \mathrm{mL}^{-1}(\mathrm{a}, \mathrm{c}) ; 37,5 \mathrm{mg} \mathrm{mL}^{-1}(\mathrm{~b}, \mathrm{~d})$ 


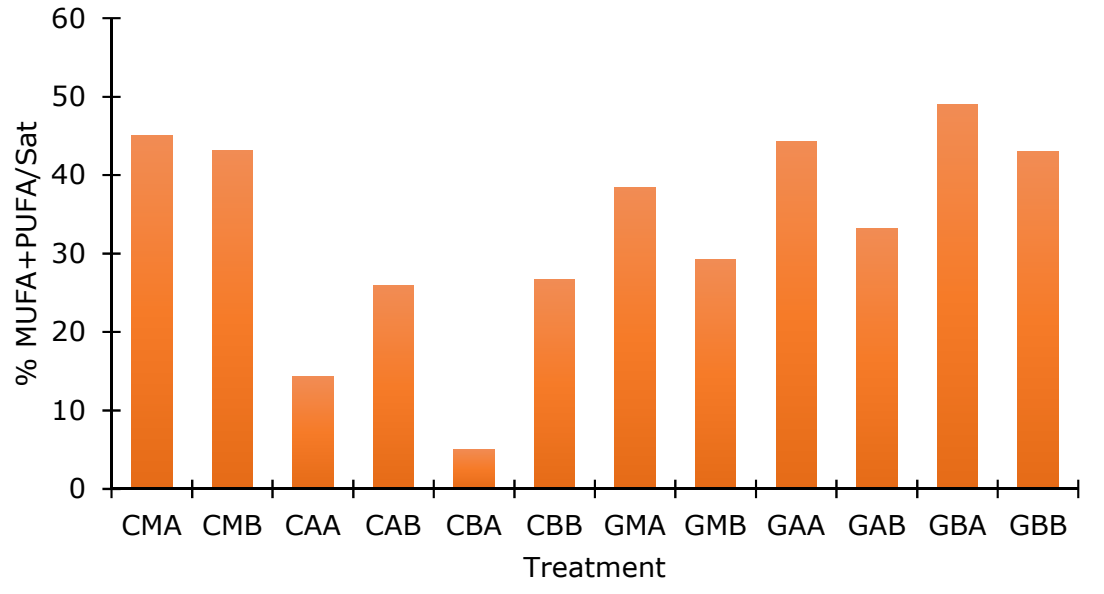

Figure 5. Mean Percentage MUFA+PUFA/ Saturated fatty acids in Chaetoceros constrictus (CMA, CMB, CAA, CAB, CBA, CBB) and Chaetoceros gracilis (GMA GMB, GAA, GAB, GBA, GBB) for each treatment according to Table 1 / Promedio del porcentaje de MUFA+PUFA/Acidos grasos saturados en Chaetoceros constrictus (CMA, $\mathrm{CMB}, \mathrm{CAA}, \mathrm{CAB}, \mathrm{CBA}, \mathrm{CBB}$ ) y Chaetoceros gracilis (GMA, GMB, GAA, GAB, GBA, GBB) para cada tratamiento según la Tabla 1

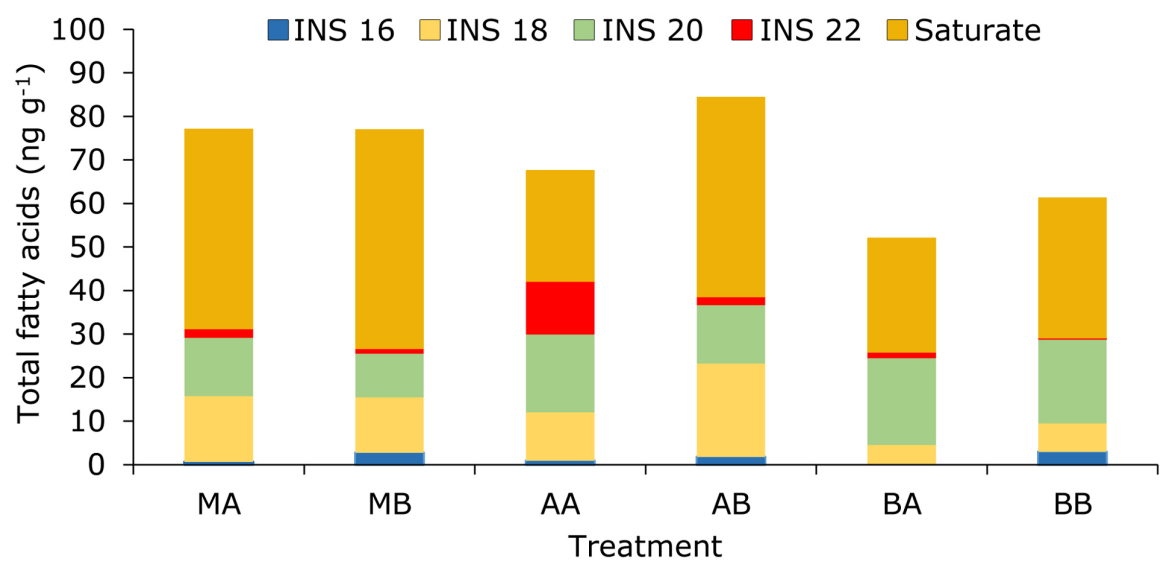

Figure 6. Distribution of main groups of fatty acid content in each treatment, in Chaetoceros gracilis. Unsaturated fatty acids (MUFA+PUFA) C16, C18, C20, C22 and SFA (saturated fatty acids C14, C16, C18, C20, C22). MUFA: monounsaturated fatty acid. PUFA: polyunsaturated fatty acids, chains of fatty acids with two or more double bond between carbons. MA: moderate or normal irradiance, and normal or high sodium nitrate in $\mathrm{F} / 2$ culture medium, MB: moderate or normal irradiance, and low sodium nitrate in F/2 culture medium, AA; high irradiance, and normal or high sodium nitrate in $\mathrm{F} / 2$ culture medium, $\mathrm{AB}$ : moderate or normal irradiance, and low sodium nitrate in $\mathrm{F} / 2$ culture medium, $\mathrm{BA}$ : low irradiance, and normal or high sodium nitrate in F/2 culture medium, BB: low irradiance and low sodium nitrate in F/2 culture medium / Distribución de los principales grupos de contenido de ácidos grasos en cada tratamiento, en Chaetoceros gracilis. Ácidos grasos insaturados (MUFA + PUFA) C16, C18, C20, C22 y SFA (ácidos grasos saturados C14, C16, C18, C20, C22). MUFA: ácido graso monoinsaturado. PUFA: ácidos grasos poliinsaturados, cadenas de ácidos grasos con dos o más enlaces dobles entre el carbono. MA: intensidad lumínica normal o moderada y concentración normal o alta de nitrato de sodio en el medio F/2 MB: intensidad lumínica normal o moderada y concentración baja de nitrato de sodio en el medio F/2, AA: intensidad lumínica alta y concentración normal o alta de nitrato de sodio en el medio $F / 2, A B$ : intensidad lumínica normal o moderada y concentración baja de nitrato de sodio en el medio F/2, BA: intensidad lumínica baja y concentración normal o alta de nitrato de sodio en el medio F/2, BB: intensidad lumínica baja y concentración baja de nitrato de sodio en el medio $\mathrm{F} / 2$

In general, C. constrictus presented a predominance of saturated fatty acids (SFA) over unsaturated (Fig. 7).

The production of $\mathrm{C}$ 16:3 fatty acids was higher in $C$. constrictus than $C$. gracilis for both low and high nitrate concentrations, with statistical significance $(P<0.0001)$.

According to the results, there are statistically significant differences between fatty acid production levels when comparing C 16:3 fatty acids, with higher concentrations observed in $C$. constrictus than $C$. gracilis $(P=0.0063)$. The contrary occurs with C $18: 1 ;$ C. gracilis produced higher fatty acid concentrations in high nitrate concentration $(P=$ 0.0043) (Fig. 8a, b). Unsaturated C 18 was higher in $C$. gracilis than $C$. constrictus (statistically significant, $P<$ $0.0001)$.

In relation to the low, medium and high irradiance levels tested, the values observed in $C$. constrictus were higher than in $C$. gracilis for C 16:3 fatty acids, as in the case of nitrate concentration. C 18:1 and C 20:5 values were higher 


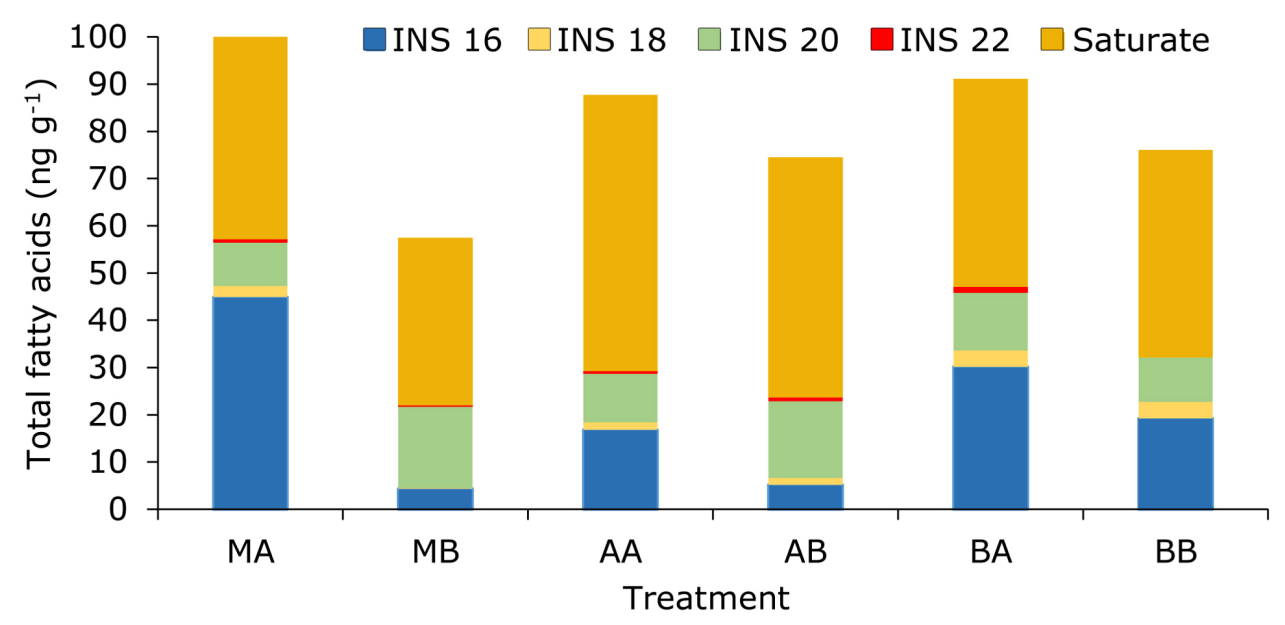

Figure 7. Distribution of main groups of fatty acid content in each treatment, in Chaetoceros constrictus. Unsaturated fatty acids (MUFA+PUFA) C16, C18, C20, C22 and SFA (saturated fatty acids C14, C16, C18, C20, C22). Abbreviations according to Figure 6 / Distribución del contenido de los principales grupos de ácidos grasos en cada tratamiento, en Chaetoceros constrictus. Ácidos grasos insaturados (MUFA + PUFA) C16, C18, C20, C22 y SFA (ácidos grasos saturados C14, C16, C18, C20, C22). Abreviaturas según la Figura 6

in C. gracilis than C. constrictus. In C. constrictus, fatty acid concentration increased with greater irradiance, whereas in C. gracilis it tended to decrease.

Fatty acid distribution identified in each treatment for both species of Chaetoceros is presented in Figure 8a, b, where one can see the differences in fatty acid composition for each treatment, as well as differences between species.

\section{FATTY ACIDS PRODUCTION OF CHAETOCEROS GRACILIS}

With irradiance and nitrate concentrations, C. gracilis produced similar concentrations of saturated and unsaturated fatty acids of $\mathrm{C} 16$ (C16:2), $\mathrm{C} 18$ (C18:2) and $\mathrm{C} 20$ (C20:5), as well as reduced concentrations of unsaturated C22 (C22:6) fatty acids (Fig. 8a).

Under stress conditions (low nitrate concentration) at normal irradiance, total lipids and saturated fatty acids increased proportionally, maintaining the concentration of unsaturated $\mathrm{C} 16$ (C16:1, C16:2, C16:3), and decreasing fatty acids C18 (C18:1, C18:3), C20 (C20:5) and C22 (C22:6). C14 and C16 saturated fatty acids increased their concentration. Although absent under normal conditions, C18 stearic acid accumulated under stress conditions.

At high intensity light conditions, the difference in total lipid concentrations between normal and stress conditions was less than at normal light intensities. Under normal nitrate conditions, unsaturated fatty acids C16 (C16:1, C16: 3, C16:2), C18 (C18:1, C18:3), C20 (C20:5) and especially $\mathrm{C} 22$ (C22:5, C22:6) increased, yet total saturated fatty acid concentrations remained stable. Myristic acid levels increased, palmitic acid decreased, and stearic acid appeared. Due to low nitrate concentrations, under stress conditions, myristic, palmitic, stearic and saturated fatty acids increased. As well as arachidic and behenic fatty acids and $\mathrm{C} 18$ unsaturated fatty acids (C18:2 fatty acid appeared); $\mathrm{C} 16$ unsaturated fatty acids decreased drastically (C16:1 and C16:2 appeared, yet C16:3 disappeared), along with $\mathrm{C} 20$ and unsaturated C22 (C22:5 disappeared, C22:6 decreased) (Figure 8a).

At low light intensity, total lipid production is almost equal, yet slightly lower, at normal nitrate concentrations. Under normal nitrate conditions there was less saturated fatty acids and unsaturated $\mathrm{C} 18$ production (under normal nitrate conditions oleic acid is produced and under stress conditions it decreases and linolenic appears), but increased unsaturated $\mathrm{C} 22(\mathrm{C} 22: 6)$ than in stress conditions. Specifically, in normal nitrate conditions, there is higher myristic and less palmitic, stearic and behenic production. The main difference is in palmitic acid production. Total C20 unsaturated fatty acids remained unchanged; C20:5 is produced under normal conditions, which decreases under stress conditions, generating C20:4. Under stress conditions, palmitoleic acid decreases slightly.

\section{FAtTy ACIDS PROduction of Chattoceros CONSTRICTUS}

Under normal irradiance, normal nitrate concentration, and stress conditions, there were similar total lipid concentrations (Fig. 8b). Under normal conditions, there were equivalent unsaturated $\mathrm{C} 16$ concentrations (with predominance of C16:1 and lower concentration of C16:3). Total saturated fatty acids (with similar concentrations of 
a)

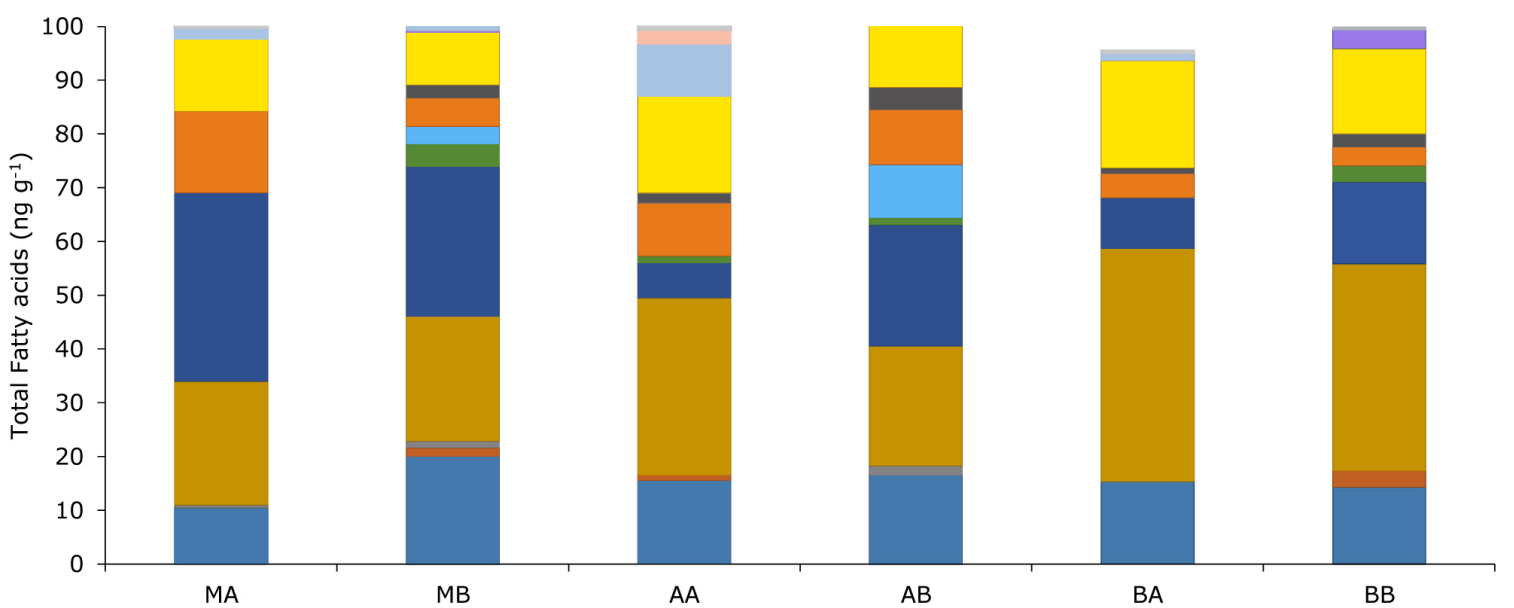

b)

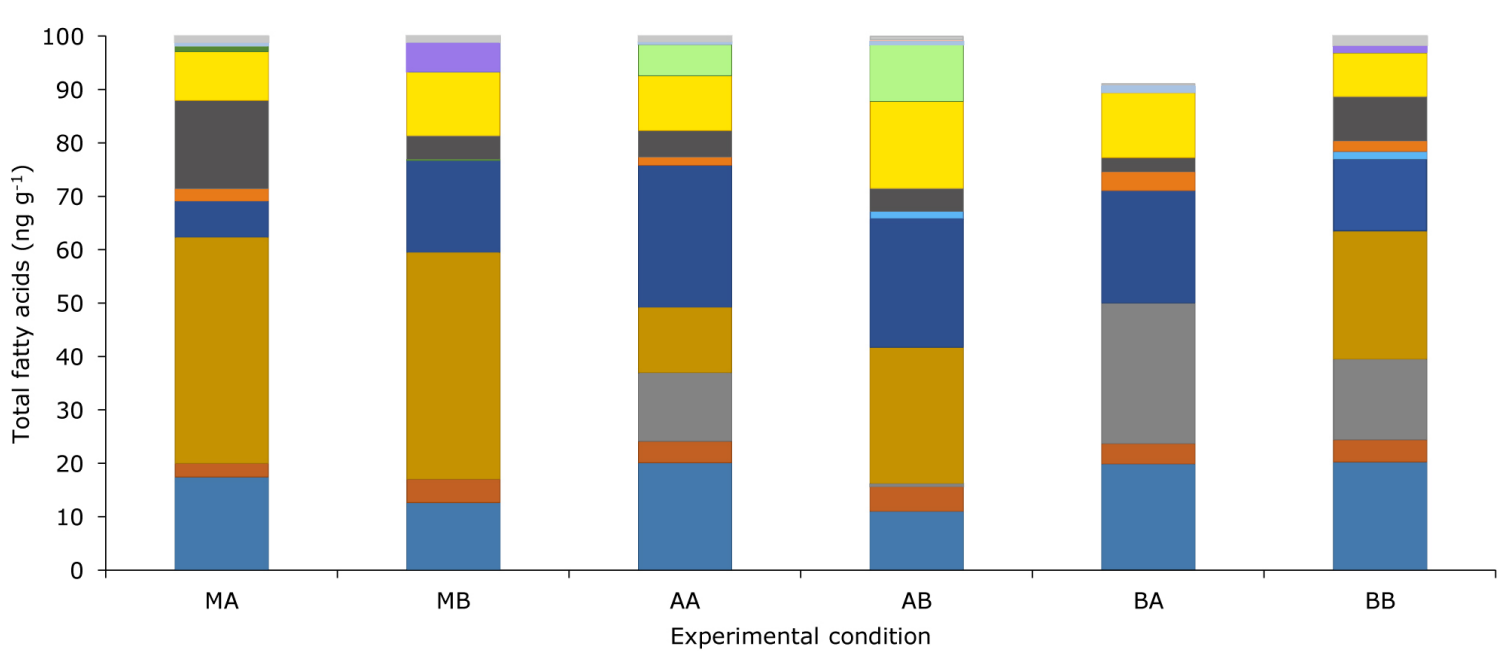

Figure 8. Distribution of fatty acid content in each treatment, identify each fatty acid with carbon number and the number of double bond in the molecule in: a) Chaetoceros gracilis and b) Chaetoceros constrictus. Abbreviations according to Figure 6 / Distribución del contenido de ácidos grasos en cada tratamiento, identifica cada ácido graso con el número de carbonos y el número de dobles enlaces en la molécula en: a) Chaetoceros gracilis y b) Chaetoceros constrictus. Abreviaturas según la Figura 6

myristic and stearic acid) were increased. Less palmitic and much less arachidic and behenic acids were observed, as well as reduced unsaturated $\mathrm{C} 18$ (C18:1), C20 (C20:5), and $\mathrm{C} 22$ (C22:6) concentrations.

Under stress conditions, we observed differences in unsaturated C16 (similar C16:1 and higher C16:3 concentrations than normal nitrate conditions) and $\mathrm{C} 20$ (higher C20:5 concentration than in normal conditions; C20:4 appeared), furthermore there were no unsaturated C18 and $\mathrm{C} 22$ fatty acids. The myristic and stearic saturated fatty acids decreased, C22 levels were maintained and palmitic acid concentration increased (Fig. 8b).

In conditions of high irradiance in C. constrictus, there was a greater diversity of fatty acids present, with total lipid concentrations similar to normal irradiance, with saturated fatty acids predominating over unsaturated fatty acids; the latter increased under stress conditions. At normal nitrate concentrations, myristic and palmitic acids were present, which decrease their concentration under stress conditions, and arachidic acid is increased. Stearic acid concentration remained the same under both conditions. Unsaturated C16:1 increased in stress conditions, C16:2 decreased and C16:3 remained the same. Unsaturated C18:1 appeared under normal conditions and $\mathrm{C} 18: 2$ under stress conditions; C20:5 increased under stress conditions and traces of C22:5 were observed.

With low irradiance and normal nitrate concentrations, there was some decrease in total lipids; however, under stress conditions total lipids were higher and very similar to those obtained in the previous conditions. Saturated fatty acids under normal conditions were similar to those obtained under stress conditions. Myristic acid maintained its levels in both conditions. Palmitic acid decreased under 
stress conditions, whereas stearic acid and behenic acid increased. Unsaturated C16 (C16:3 and C16:2 decreased; C16:1 concentration was the highest) was higher than $\mathrm{C} 18$ (in normal conditions C18:1 only decreased under stress conditions and C18:2 appeared in equal concentration) and $\mathrm{C} 20: 5$, which is higher under normal conditions. Unsaturated C22:6 were very low and practically did not appear under stress conditions, being replaced by C20:4.

\section{FATTY ACIDS PRODUCTION OF CHAETOCEROS GRACILIS AND CHAETOCEROS CONSTRICTUS}

In C. gracilis there was no $\mathrm{C} 18: 0$ produced under conditions of moderate illumination and high nitrate concentration, while in $C$. constrictus the range was $5.93-26.9 \mathrm{ng} \mathrm{g}^{-1}$. In $C$. constrictus there was no $\mathrm{C} 18: 1$ produced under conditions of high and moderate irradiance and low nitrate concentrations, while in C. gracilis the range was 0-10.62 and 0-20.55 $\mathrm{ng} \mathrm{g}^{-1}$, respectively. In $C$. gracilis there was no $\mathrm{C} 16: 3$ produced in high nitrate concentrations and low to moderate irradiance, nor in low nitrate concentration with high irradiance, whereas in $C$. gracilis the range was $0.36-7.25,2.31-2.68$, and 4.4-4.86 $\mathrm{ng} \mathrm{g}^{-1}$, respectively. In C. constrictus there was no $\mathrm{C} 22: 6$ produced, with low irradiance and low nitrate concentration, while in $C$. gracilis the range was $0-0.51 \mathrm{ng}$ $\mathrm{g}^{-1}$. The production of polyunsaturated fatty acids is favoured by high irradiance in $C$. constrictus and $C$. gracilis, and when low irradiance and low sodium nitrate concentration were combined in C. gracilis (Fig. 5).

The overall statistical analysis of the combined effect of irradiance and sodium nitrate concentration on fatty acid concentration produced species-specific responses.

While in C. gracilis significant positive or negative correlations occur between fatty acids of lower carbon numbers (myristic acid) and those with higher carbon numbers, in $C$. constrictus myristic acid present no correlation with other fatty acids, acids of $\mathrm{C}: 16$ or $\mathrm{C}: 18$ (Fig. 9a, b).

a)

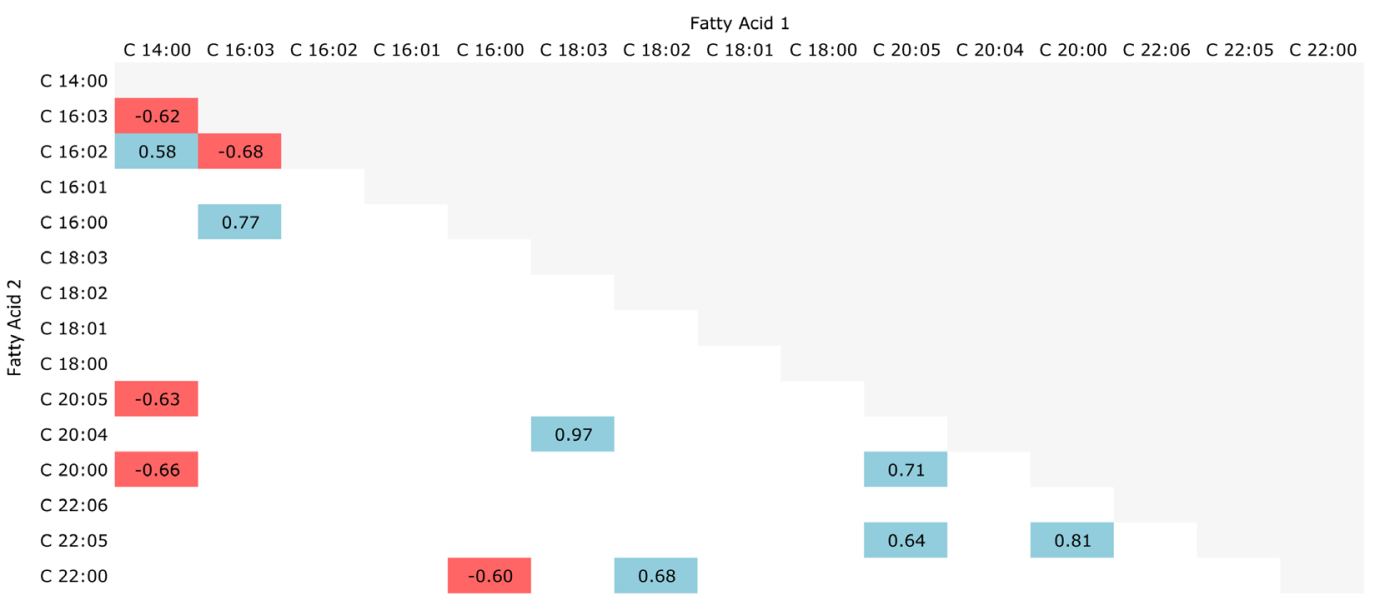

b)

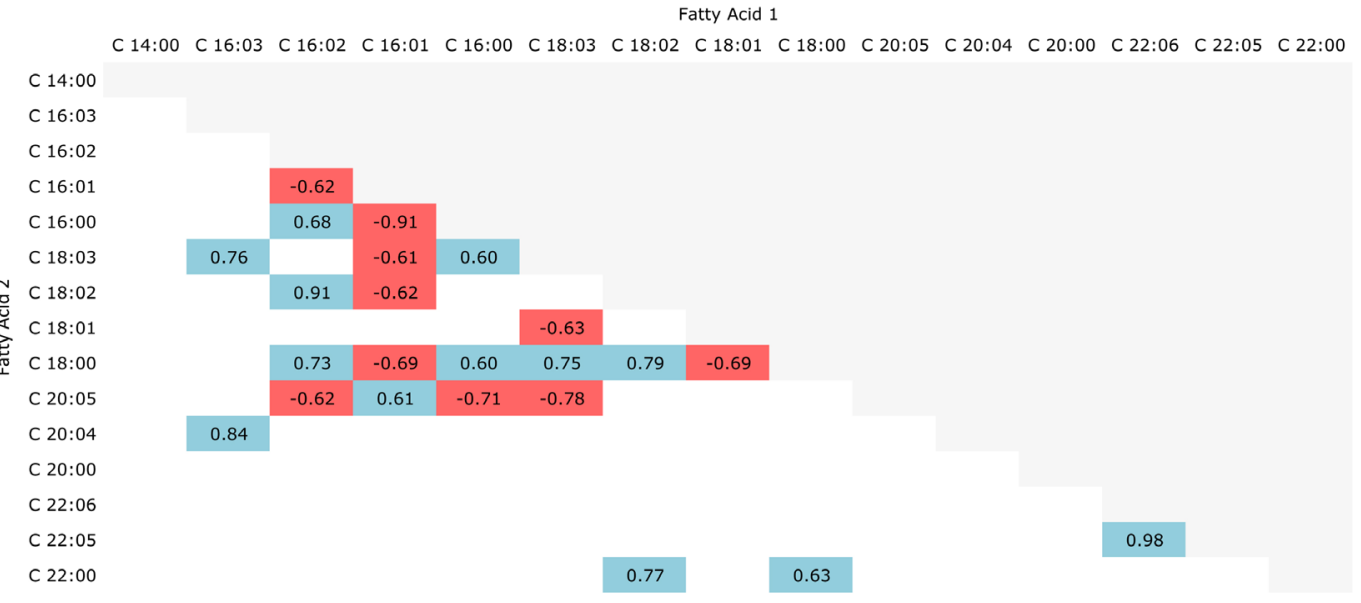

Figure 9. Matrix showing Pearson Correlation Coefficient significant statistically between fatty acids pairs, both in the experimental control in: a) Chaetoceros gracilis and b) Chaetoceros constrictus. Positive coefficients between pairs are in blue and the negative coefficients in red / Matriz que muestra el coeficiente de correlación de Pearson estadísticamente significativo entre los pares de ácidos grasos, tanto en el control experimental como en: a) Chaetoceros gracilis y b) Chaetoceros constrictus. Los coeficientes positivos entre pares están en azul y los negativos en rojo 
Principal component analysis revealed that the metabolic pathway responses to different irradiance conditions and nitrate concentration levels were different for PUFA, MUFA, SAT, EPA and DHA production (Fig. 10; Table 2). The best correlation that explains CP1, with $49 \%$ variance in Figure 10, is shown by unsaturated C20 (Table 2). In Figure 10, EPA, presented the best correlation with CP1.

During correlation analysis between fatty acid concentrations in the different test conditions, there are positive correlations between pairs of fatty acids, which implies a metabolic pathway whereby increases in one of the fatty acids engender increases in the other, or vice versa when the correlation is negative (Figs. 9a, b)
Table 2. Correlation between original variables and the first two principal components in PCA analysis shown in Figure $\mathbf{6}$ / Correlación entre las variables originales y los dos primeros componentes principales en el análisis de PCA mostrados en la Figura 6

\begin{tabular}{lcrr}
\hline \multicolumn{1}{c}{ Lipid content } & $\begin{array}{c}\text { Variables } \\
\text { label }\end{array}$ & PCA1 & \multicolumn{1}{c}{ PCA2 } \\
\hline Unsaturated C16 & Ins 16 & -0.7501 & -0.3311 \\
Unsaturated C18 & Ins 18 & 0.3652 & 0.8758 \\
Unsaturated C20 & Ins 20 & 0.8522 & -0.3809 \\
Unsaturated C22 & Ins 22 & 0.6562 & 0.1683 \\
Saturated FA & Saturate & -0.7879 & 0.4494 \\
EPA & C 20:05 & 0.848 & -0.286 \\
DHA & C 22:06 & 0.729 & 0.008 \\
\hline
\end{tabular}

Cophenetic correlation $=0.937$

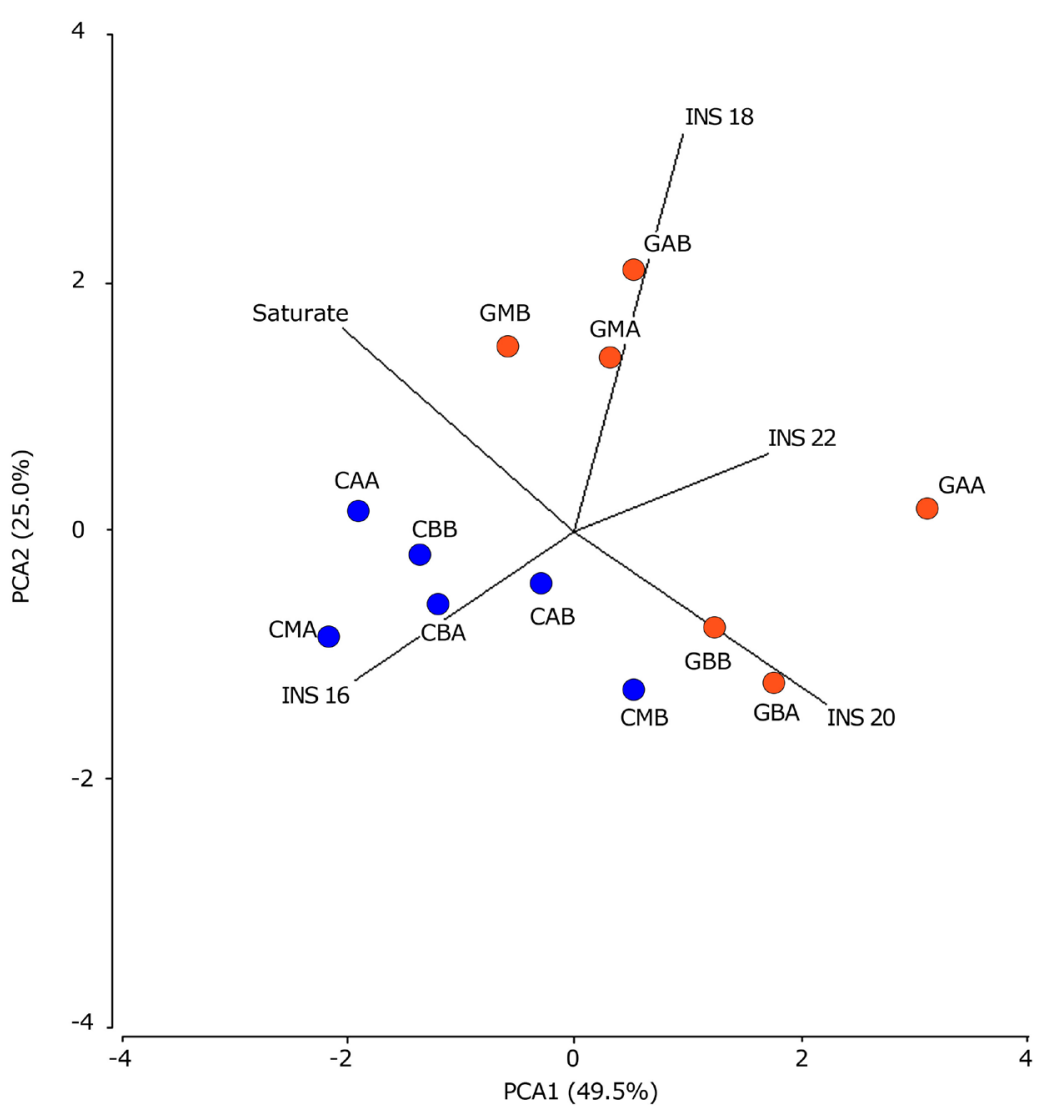

Figure 10. Vector diagram indicating the loading on PCA1 and PCA2 of biochemical composition of Chaetoceros constrictus (blue dot) and Chaetoceros gracilis (orange dot) for each treatment. Cophenetic correlation index= 0.94 / Diagrama vectorial que indica la carga en PCA1 y PCA2 de la composición bioquímica de Chaetoceros constrictus (punto azul) y Chaetoceros gracilis (punto naranja) para cada tratamiento. Índice de correlación cofenética=0,94 


\section{EICOSAPENTAENOIC ACID PRODUCTION}

Eicosapentaenoic acid production in both species of Chaetoceros is presented in Figure 11a for C. gracilis and Figure $11 \mathrm{~b}$ for $C$. constrictus. In the same graph, one can observe the biomass (wet and dry weight) for each treatment. In $C$. gracilis, both high and low irradiance and normal nitrate concentrations produced higher levels of EPA than normal irradiance and nitrate levels. In $C$. constrictus, high irradiance and low nitrate concentration (stress) produced higher EPA concentration than the control.

\section{Discussion}

Photosynthetic organisms can produce the total polyunsaturated fatty acids that they need for living (Guschina \& Harwood 2009). Heterotrophs can get it from food, their different metabolic pathways can modify fatty acids by desaturases and elongases, given rise to a diversity of new compounds necessary for growth (Brett \& MüllerNavarra 1997, Fang et al. 2004, Ho et al. 2007, Monroig et al. 2013), and therefore they are essential nutrients for aquaculture. Colombo et al. (2018), in a recent review, concluded that omega n-3 long chain PUFA content is dependent on taxonomy (Galloway \& Winder 2015) and latitude. Low temperatures engender increased unsaturated fatty acid content to improve cell membrane fluidity (Sasaki et al. 2006, Bell et al. 1986) and maintain cellular homeostasis. According to Cohen et al. (2000), PUFA are rapidly mobilized from triacylglicerides that function as a depot to respond to low temperature stress and high pressure, as demonstrated by Fang et al. (2004). Also in ovigerous females of crustacean Pleuroncodes monodon was found that the fatty acids composition varies according seasonally (Bascur et al. 2017).

Isochrysis galbana produced higher levels of linolenic acid and docosahexaenoic acid than eicosapentaenoic acid (EPA) at low N-nitrate concentration however, fatty acids increased notably with surplus N-nitrate, above F/2 medium content. Besides, Isochrysis zhangjiangensis can accumulate lipids under nitrogen-repletion conditions and carbohydrates under nitrogen-depletion conditions (Feng et al. 2011). Regarding protein content, an increase was found in relation to high nitrate content in the medium. These findings are in accordance with those reported for diatoms by De La Peña et al. (2007) and Yodsuwan et al. (2017)

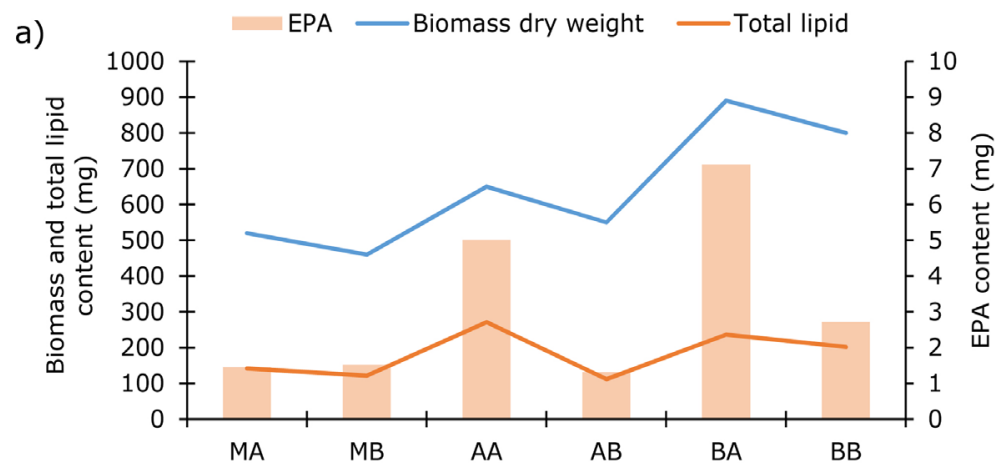

b)

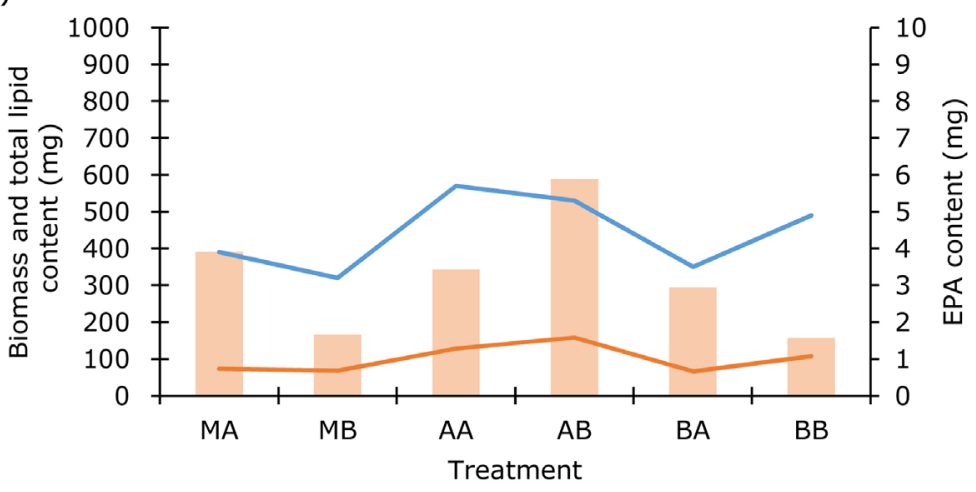

Figure 11. Total lipid content, dry weight of biomass and production of eicosapentaenoic acid in each treatment in: a) Chaetoceros gracilis and b) Chaetoceros constrictus / Total de lípidos, peso seco de la biomasa y producción de ácido eicosapentaenoico en cada tratamiento en: a) Chaetoceros gracilis y b) Chaetoceros constrictus 
and for Chlorella vulgaris (Chen et al. 2015). Caporgno \& Mathys (2018) suggest that microalgae are a new source of proteins for feeding. Moreover, Sukenik \& Livne (1991) found in Isochrysis galbana, that limited nitrogen in the culture medium correlated with acetyl CoA carboxylase and malonyl CoA synthesis, which are necessary for fatty acid production.

As average irradiance increases, saturated and monounsaturated fatty acid percentages decreased, increasing the proportion of EPA. By taking into account the different relations between EPA content and irradiance, EPA productivity variation over the year can be simulated as a function of average and external irradiance. Irradiance was selected according to previous studies, which concluded that low intensity favors PUFA production (Grima et al. 1992, Solovchenko et al. 2008, Khoeyi et al. 2012).

In this study, the increase in DHA concentration observed under $160 \mathrm{mg} \mathrm{L}^{-1}$ sodium nitrate concentration, could be explained by Huerlimann et al. (2014), who found that the plastidial acetyl CoA carboxylase enzyme is stimulated in I. aff. galbana (during the logarithmic phase) in cultures with sodium nitrate overload. This was not observed for Chaetoceros species, where the main concentrations were under limited nitrate conditions, corroborating that this is a species-specific response (Huerlimann et al. 2014).

In the present study, there is some evidence of specific differences in the results. According to Napolitano et al. (1997), high C14:0, C16:4 and C20:5 concentrations are due to a diatom in the phytoplankton. Mortensen et al. (1988) found the same results in Chaetoceros gracilis at temperature of 18 and $20^{\circ} \mathrm{C}$ in batch cultures. In both Chaetoceros species, we observed correlations between fatty acid pairs; these results suggest that there are different metabolic pathways for the factors (irradiance and nitrate) tested. It bears noting that our experiments were performed at lower temperatures than those reported in the literature (Renaud et al. 2002, van Wagenen et al. 2012, Miller et al. 2014).

In addition to acclimatization, $C$. constrictus was isolated from environmental samples taken in Coliumo Bay (Dichato); Chaetoceros spp. are an important quantitative component in phytoplankton composition, especially during spring (August to November) (Rivera 1969) in an upwelling event (González et al. 1987).

Thus, whereas in $C$. gracilis myristic acid (C14:0) is negatively correlated with hexadecatrienoic acid (C16:3), eicosanoic acid (C20:0), eicosapentaenoic acid (C20:5) and docosapentaenoic acid (C22:5), in C. constrictus palmitic acid (C16:0) is negatively correlated with palmitoleic acid (C16:1), oleic acid (C18:1) and eicosapentaenoic acid (C20:5), yet positively correlated with stearic acid (C18:0), hexadecadienoic acid and linolenic acid (C18:3).
High irradiation conditions favored saturated and unsaturated $\mathrm{C} 16$ and saturated and monounsaturated C18 fatty acid production, a metabolic pathway which occurs specifically in the chloroplast; these fatty acids can be stored in adverse growth conditions (Hu et al. 2008).

Variations in irradiance will affect the chloroplast metabolism, and therefore fatty acid biosynthesis in the prokaryotic chloroplast pathway (Mühlroth et al. 2013). Therefore, it can exclude docosapentaenoic acid, linolenic acid, eicosanoic acid, and eicosapentaenoic acid, which come from the endoplasmic reticulum, and were synthesized due to the stress caused by low nitrate availability in the medium (Hu et al. 2008).

In this study, we found that saturated fatty acid concentrations increased considerably in C. constrictus with high irradiation, although they were slightly lower in the case of limited nitrate in the culture medium when compared to normal nitrate concentrations. In normal nitrate conditions, twice as much myristic fatty acid content was produced than in reduced nitrate concentrations. PUFA+MUFA production at low irradiance was lower than normal irradiance. Some species, such as Chlorella vulgaris, Chromochloris zofingiensis, Ettlia oleoabundans, and Tetradesmus obliquus, can accumulate approximately $35 \%$ of their dry weight as triacylglycerols in poor nitrogen conditions (Breuer et al. 2012), palmitic acid and oleic acid predominating. Similarly to Breuer et al. (2012), recorded growth rate and biomass were highest for $C$. constrictus at high irradiation conditions. Hu et al. (2008) found that many microalgae could accumulate large quantities of lipids as TAGs under environmental stress conditions (e.g. nitrogen starvation). They explained that TAGs are energy and carbon storage compounds when photosynthesis exceeds growth requirements ( $\mathrm{Hu}$ et al. 2008). EPA is mainly obtained from fish oil, but microalgae such C. constrictus could also be a good source - with high irradiation and low nitrate concentrations in the F/2 medium - of oils with a simpler composition than fish oil, as demonstrated with Phaeodactylum tricornutum (Domergue et al. 2003, Haro et al. 2017).

The findings presented in this paper answered the hypothesis, which regarded the culture conditions that engender increased unsaturated fatty acids in Isochrysis galbana, Chaetoceros gracilis and C. constrictus in batch conditions. Different profiles of fatty acids were obtained at different irradiance and nitrate concentration, both in Chaetoceros sp. and Isochrysis galbana given the opportunity to a hatchery manager to bring the best mix for feeding. Cerpa et al. (2003) reported on a mix of microalgae for Argopecten purpuratus broodstock conditioning with 4 treatments in a hatchery and at the sea as control. On the other hand, larval bivalve feeding composed of Chaetoceros calcitrans and Isochrysis galbana (1:1) would achieve 
successful metamorphosis due to a balanced diet based on fatty acid composition (Farias et al. 2003, Rico-Villa et al. 2006, Pettersen et al. 2010, Ragg et al. 2010). It was found that Isochrysis galbana and Chaetoceros spp. fatty acids profiles vary in relation to number of carbons of fatty acids (Napolitano et al. 1990). In this study it was shown that depends on nitrate availability and irradiance the same species could vary the concentration of some components. The results presented herein provide support to take some microalgae culture conditions into account, and optimize nutrition for both larvae and broodstock. For I. galbana especially, the high nitrate $\left(160 \mathrm{mg} \mathrm{L}^{-1}\right)$, protein and PUFA culture is highly recommended for broodstock conditioning, since Cerpa et al. (2003) found reduced high molecular weight polypeptide content in the gonad of Argopecten purpuratus specimens raised in hatcheries compared to ocean-bred (Velasco et al. 2016).

\section{ACKNOWLEDGMENTS}

We would thank Dr. Patricio Rivera for taxonomic identification of Chaetoceros constrictus and Ing. Gabriel Seguel for graphs.

\section{LITERATURE CITED}

Adarme-Vega TC, DK Lim, M Timmins, F Vernen, Y Li \& PM Schenk. 2012. Microalgal biofactories: a promising approach towards sustainable omega-3 fatty acid production. Microbial Cell Factories 11: 96. <https://doi. org/10.1186/1475-2859-11-96>

Bascur M, F Guzmán, S Mora \& A Urzúa. 2017. Seasonal changes in the biochemical composition of females and offspring of red squat lobster, Pleuroncodes monodon (Decapoda, Munididae), from the Southeastern Pacific. Marine Ecology 38(2). <https://DOI: 10.1111/maec.12419>

Bell MV, RJ Henderson \& JR Sargent. 1986. The role of polyunsaturated fatty acids in fish. Comparative Biochemistry and Physiology Part B: Comparative Biochemistry 83(4): 711-719.

Bellou S, MN Baeshen, AM Elazzazy, D Aggeli, F Sayegh \& G Aggelis. 2014. Microalgal lipids biochemistry and biotechnological perspectives. Biotechnology Advances 32(8): 1476-1493.

Benavente-Valdés JR, C Aguilar, JC Contreras-Esquivel, A Méndez-Zavala \& J Montañez. 2016. Strategies to enhance the production of photosynthetic pigments and lipids in Chlorophycae species. Biotechnology Reports 10: 117-125.

Bonacic K, C Campoverde, M Sastre, I Hachero-Cruzado, M Ponce, M Manchado \& S Morais. 2016. Mechanisms of lipid metabolism and transport underlying superior performance of Senegalese sole (Solea senegalensis, Kaup 1858) larvae fed diets containing n-3 polyunsaturated fatty acids. Aquaculture 450: 383-396.

Brett M \& D Müller-Navarra. 1997. The role of highly unsaturated fatty acids in aquatic foodweb processes. Freshwater Biology 38(3): 483-499.
Breuer G, PP Lamers, DE Martens, RB Draaisma \& RH Wijffels. 2012. The impact of nitrogen starvation on the dynamics of triacylglycerol accumulation in nine microalgae strains. Bioresource Technology 124: 217-226.

Caporgno MP \& A Mathys. 2018. Trends in microalgae incorporation into innovative food products with potential health benefits. Frontiers in Nutrition 5: 58. < doi: 10.3389/ fnut.2018.00058>

Castro LR, G Claramunt, HE González, MC Krautz, A Llanos-Rivera, J Méndez, W Schneider \& S Soto. 2010. Fatty acids in eggs of anchoveta Engraulis ringens during two contrasting winter spawning seasons. Marine Ecology Progress Series 420: 193-205.

Cerpa J, F González, J Becerra \& I Lépez. 2003. Lipid and polypeptide profiles in the female portion of gonads from diet conditioned broodstock of North Chilean Scallops Argopecten purpuratus. North American Journal of Aquaculture 65: 1-7.

Chen CY, PJ Lee, CH Tan, YC Lo, CC Huang, PL Show, CH Lin \& JS Chang. 2015. Improving protein production of indigenous microalga Chlorella vulgaris FSP-E by photobioreactor design and cultivation strategies. Biotechnology Journal 10(6): 905-914.

Cohen Z, I Khozin-Goldberg, D Adlerstein \& C Bigogno. 2000. The role of triacylglycerol as a reservoir of polyunsaturated fatty acids for the rapid production of chloroplastic lipids in certain microalgae. Biochemical Society Transactions 28, Part 6: 740-743.

Colombo SM, LG Campbell, EJ Murphy, SL Martin \& MT Arts. 2018. Potential for novel production of omega-3 long-chain fatty acids by genetically engineered oilseed plants to alter terrestrial ecosystem dynamics. Agricultural Systems 164: 31-37.

De la Peña MR. 2007. Cell growth and nutritive value of the tropical benthic diatom, Amphora sp., at varying levels of nutrients and light intensity, and different culture locations. Journal of Applied Phycology 19(6): 647-655.

Di Rienzo JA, F Casanoves, M Balzarini, L Gonzalez, M Tablada \& CW Robledo. 2015. InfoStat versión 2014. Grupo InfoStat, FCA, Universidad Nacional de Córdoba, Argentina. $<$ http://www.infostat.com.ar $>$

Domergue F, P Spiekermann, J Lerchl, C Beckmann, O Kilian, PG Kroth \& E Heinz. 2003. New insight into Phaeodactylum tricornutum fatty acid metabolism. Cloning and functional characterization of plastidial and microsomal $\Delta 12$-fatty acid desaturases. Plant Physiology 131(4): 16481660.

EI Menyawi I, M Borgerbauer, H Sigmund, H Burgmann \& W Graniger. 2000. Identification of yeast fatty acid profiling as measured by gas-liquid chromatography. Journal of Chromatography 742B: 13-24.

Fakhrina MN \& A Christianus. 2018. Production of tropical oyster seed in hatchery. Survey in Fisheries Sciences 5(1): 7-19.

Fang J, C Kato, T Sato, O Chan \& D McKay. 2004. Biosynthesis and dietary uptake of polyunsaturated fatty acids by piezophilic bacteria. Comparative Biochemistry and Physiology Part B: Biochemistry and Molecular Biology 137(4): 455-461. 
Farias A, JG Bell, I Uriarte \& JR Sargent. 2003. Polyunsaturated fatty acids in total lipid and phospholipids of Chilean scallop Argopecten purpuratus (L.) larvae: effects of diet and temperature. Aquaculture 228(1-4): 289-305.

Feng D, Z Chen, $S$ Xue \& W Zhang. 2011. Increased lipid production of the marine oleaginous microalgae Isochrysis zhangjiangensis (Chrysophyta) by nitrogen supplement. Bioresource Technology 102(12): 6710-6716.

Folch J, M Lees \& GM Sloane-Stanley. 1957. A simple method for the isolation and purification of total lipids from animal tissues. The Journal of Biological Chemistry 226: 497-509.

Galloway AW \& M Winder. 2015. Partitioning the relative importance of phylogeny and environmental conditions on phytoplankton fatty acids. PLoS One 10(6): e0130053. $<$ https://doi.org/10.1371/journal.pone.0130053>

Gordillo FJ, M Goutx, FL Figueroa \& FX Niell. 1998. Effects of light intensity, $\mathrm{CO}_{2}$ and nitrogen supply on lipid class composition of Dunaliella viridis. Journal of Applied Phycology 10(2): 135-144.

Grima EM, JS Pérez, JG Sánchez, FG Camacho \& DL Alonso. 1992. EPA from Isochrysis galbana. Growth conditions and productivity. Process Biochemistry 27(5): 299-305.

González HE, P Bernal \& R Ahumada. 1987. Desarrollo de dominancia local en la taxocenosis de fitoplancton de Bahía de Concepción, Chile, durante un evento de surgencia. Revista Chilena de Historia Natural 60(1): 19-35.

Guevara M, BO Arredondo-Vega, Y Palacios, K Sáez \& PI Gómez. 2016. Comparison of growth and biochemical parameters of two strains of Rhodomonas salina (Cryptophyceae) cultivated under different combinations of irradiance, temperature, and nutrients. Journal of Applied Phycology 28(5): 2651-2660.

Guschina IA \& JL Harwood. 2009. Algal lipids and effect of the environment on their biochemistry. In: Kainz M, MT Brett \& MT Arts (eds). Lipids in aquatic ecosystems, pp. 1-24. Springer, New York.

Hamre K, M Yúfera, I Rønnestad, C Boglione, LE Conceição \& M Izquierdo. 2013. Fish larval nutrition and feed formulation: knowledge gaps and bottlenecks for advances in larval rearing. Reviews in Aquaculture 5(1): S26-S58.

Haro P, K Sáez \& PI Gómez. 2017. Physiological plasticity of a Chilean strain of the diatom Phaeodactylum tricornutum: the effect of culture conditions on the quantity and quality of lipid production. Journal of Applied Phycology 29(6): 2771-2782.

Hemaiswarya S, R Raja, RR Kumar, V Ganesan \& C Anbazhagan. 2011. Microalgae: a sustainable feed source for aquaculture. World Journal of Microbiology and Biotechnology 27(8): 1737-1746.

Ho SY, Y Jiang \& F Chen. 2007. Polyunsaturated fatty acids (PUFAs) content of the fungus Mortierella alpina isolated from soil. Journal of Agricultural and Food Chemistry 55(10): 3960-3966.

Hu Q, M Sommerfeld, E Jarvis, M Ghirardi, M Posewitz, M Seibert \& A Darzins. 2008. Microalgal triacylglycerols as feedstocks for biofuel production: Perspectives and advances. The Plant Journal 54(4): 621-639.
Huerlimann R, EJ Steinig, H Loxton, KR Zenger, DR Jerry \& K Heimann. 2014. The effect of nitrogen limitation on acetyl-CoA carboxylase expression and fatty acid content in Chromera velia and Isochrysis aff. galbana (T-ISO). Gene 543(2): 204-211.

Kim G, G Mujtaba \& K Lee. 2016. Effects of nitrogen sources on cell growth and biochemical composition of marine chlorophyte Tetraselmis sp. for lipid production. Algae 31(3): 257-266.

Khoeyi ZA, J Seyfabadi \& Z Ramezanpour. 2012. Effect of light intensity and photoperiod on biomass and fatty acid composition of the microalgae, Chlorella vulgaris. Aquaculture International 20(1): 41-49.

Liang Y, J Beardall \& P Heraud. 2006. Changes in growth, chlorophyll fluorescence and fatty acid composition with culture age in batch cultures of Phaeodactylum tricornutum and Chaetoceros muelleri (Bacillariophyceae). Botanica Marina 49(2): 165-173.

Lourenço SO, E Barbarino, J Mancini-Filho, KP Schinke \& E Aidar. 2002. Effects of different nitrogen sources on the growth and biochemical profile of 10 marine microalgae in batch culture: an evaluation for aquaculture. Phycologia 41(2): 158-168.

Lowry OH, NJ Rosebrough, AI Farr \& RJ Randall. 1951. Protein measurement with the Folin phenol reagent. The Journal of Biological Chemistry 193(1): 265-275.

Madkour FF, AE Kamil \& HS Nasr. 2012. Production and nutritive value of Spirulina platensis in reduced cost media. The Egyptian Journal of Aquatic Research 38(1): 51-57.

Metcalfe LD, AA Schmitz \& JR Pelka. 1966. Rapid preparation of fatty acid esters from lipids for gas chromatographic analysis. Analytical Chemistry 38(3): 514-515.

Minhas AK, P Hodgson, CJ Barrow \& A Adholeya. 2016. A review on the assessment of stress conditions for simultaneous production of microalgal lipids and carotenoids. Frontiers in Microbiology 7: 546.

Miller MR, SY Quek, K Staehler, T Nalder \& MA Packer. 2014. Changes in oil content, lipid class and fatty acid composition of the microalga Chaetoceros calcitrans over different phases of batch culture. Aquaculture Research 45(10): 1634-1647.

Monroig Ó, D Tocher \& J Navarro. 2013. Biosynthesis of polyunsaturated fatty acids in marine invertebrates: recent advances in molecular mechanisms. Marine Drugs 11(10): $3998-4018$

Mortensen SH, KY Børsheim, J Rainuzzo \& G Knutsen. 1988. Fatty acid and elemental composition of the marine diatom Chaetoceros gracilis Schütt. Effects of silicate deprivation, temperature and light intensity. Journal of Experimental Marine Biology and Ecology 122(2): 173-185.

Mühlroth A, K Li, G Røkke, P Winge, Y Olsen, MF Hohmann-Marriott, O Vadstein \& AM Bones. 2013. Pathways of lipid metabolism in marine algae, co-expression network, bottlenecks and candidate genes for enhanced production of EPA and DHA in species of Chromista. Marine Drugs 11(11): 4662-4697. 
Napolitano GE, RG Ackman \& WM Ratnayake. 1990. Fatty acid composition of three cultured algal species (Isochrysis galbana, Chaetoceros gracilis and Chaetoceros calcitrans) used as food for bivalve larvae. Journal of the World Aquaculture Society 21(2): 122-130.

Napolitano GE, RJ Pollero, AM Gayoso, BA Macdonald \& RJ Thompson. 1997. Fatty acids as trophic markers of phytoplankton blooms in the Bahia Blanca Estuary (Buenos Aires, Argentina) and in Trinity Bay (Newfoundland, Canada). Biochemical Systematics and Ecology 25(8): 739-755

Pettersen AK, GM Turchini, S Jahangard, BA Ingram \& CD Sherman. 2010. Effects of different dietary microalgae on survival, growth, settlement and fatty acid composition of blue mussel (Mytilus galloprovincialis) larvae. Aquaculture 309(1): 115-124.

Ragg NL, N King, E Watts \& J Morrish. 2010. Optimising the delivery of the key dietary diatom Chaetoceros calcitrans to intensively cultured Greenshell ${ }^{\mathrm{TM}}$ mussel larvae, Perna canaliculus. Aquaculture 306(1): 270-280.

Ramírez JJ. 1982. El fitoplancton: métodos de muestreo, concentración, recuento y conservación. Actualidades Biológicas 11(39): 30-36.

Renaud SM, LV Thinh, G Lambrinidis \& DL Parry. 2002. Effect of temperature on growth, chemical composition and fatty acid composition of tropical Australian microalgae grown in batch cultures. Aquaculture 211(1-4): 195-214.

Rico-Villa B, JR Le Coz, C Mingant \& R Robert. 2006. Influence of phytoplankton diet mixtures on microalgae consumption, larval development and settlement of the Pacific oyster Crassostrea gigas (Thunberg). Aquaculture 256(1): 377-388.

Rivera P. 1969. Sinopsis de las diatomeas de la Bahía de Concepción, Chile. Gayana Botanica 18: 1-112.

Roopnarain A, SD Sym \& VM Gray. 2015. Time of culture harvest affects lipid productivity of nitrogen-starved Isochrysis galbana U4 (Isochrysidales, Haptophyta). Aquaculture 438: 12-16.

Ryckebosch E, C Bruneel, R Termote-Verhalle, C Lemahieu, K Muylaert, J Van Durme \& I Foubert. 2013. Stability of omega-3 LC-PUFA-rich photoautotrophic microalgal oils compared to commercially available omega-3 LC-PUFA oils. Journal of Agricultural and Food Chemistry 61(42): 10145-10155.

Ryckebosch E, C Bruneel, R Termote-Verhalle, K Goiris, K Muylaert \& I Foubert. 2014a. Nutritional evaluation of microalgae oils rich in omega-3 long chain polyunsaturated fatty acids as an alternative for fish oil. Food Chemistry 160: $393-400$
Ryckebosch, E, SPC Bermúdez, R Termote-Verhalle, C Bruneel, K Muylaert, R Parra-Saldivar \& I Foubert. 2014b. Influence of extraction solvent system on the extractability of lipid components from the biomass of Nannochloropsis gaditana.Journal of Applied Phycology 26(3): 1501-1510.

Santos AM, M Janssen, PP Lamers, WA Evers \& RH Wijffels. 2012. Growth of oil accumulating microalga Neochloris oleoabundans under alkaline-saline conditions. Bioresource Technology 104: 593-599.

Sasaki T, Y Konoha, T Toyoda, Y Yasaka, E Przybos \& Y Nakaoka. 2006. Correlation between thermotolerance and membrane properties in Paramecium aurelia. Journal of Experimental Biology 209(18): 3580-3586.

Solovchenko AE, I Khozin-Goldberg, S Didi-Cohen, Z Cohen \& MN Merzlyak. 2008. Effects of light intensity and nitrogen starvation on growth, total fatty acids and arachidonic acid in the green microalga Parietochloris incisa. Journal of Applied Phycology 20(3): 245-251.

Sukenik A \& A Livne. 1991. Variations in lipid and fatty acid content in relation to acetyl CoA carboxylase in the marine prymnesiophyte Isochrysis galbana. Plant and Cell Physiology 32(3): 371-378.

Tocher DR. 2015. Omega-3 long-chain polyunsaturated fatty acids and aquaculture in perspective. Aquaculture 449: 94-107.

Van Wagenen J, TW Miller, S Hobbs, P Hook, B Crowe \& M Huesemann. 2012. Effects of light and temperature on fatty acid production in Nannochloropsis salina. Energies 5(3): 731-740.

Velasco LA, S Carrera \& J Barros. 2016. Isolation, culture and evaluation of Chaetoceros muelleri from the Caribbean as food for the native scallops, Argopecten nucleus and Nodipecten nodosus. Latin American Journal of Aquatic Research 44(3): 557-568.

Yodsuwan N, S Sawayama \& S Sirisansaneeyakul. 2017. Effect of nitrogen concentration on growth, lipid production and fatty acid profiles of the marine diatom Phaeodactylum tricornutum. Agriculture and Natural Resources 51(3): 190-197.

Yu WL, W Ansari, NG Schoepp, MJ Hannon, SP Mayfield \& MD Burkart. 2011. Modifications of the metabolic pathways of lipid and triacylglycerol production in microalgae. Microbial Cell Factories 10(1): 91. <https://doi. org/10.1186/1475-2859-10-91>

Zhang YM, H Chen, CL He \& Q Wang. 2013. Nitrogen starvation induced oxidative stress in an oil-producing green alga Chlorella sorokiniana C3. PloS One 8(7): e69225. < doi: 10.1371/journal.pone.0069225> 